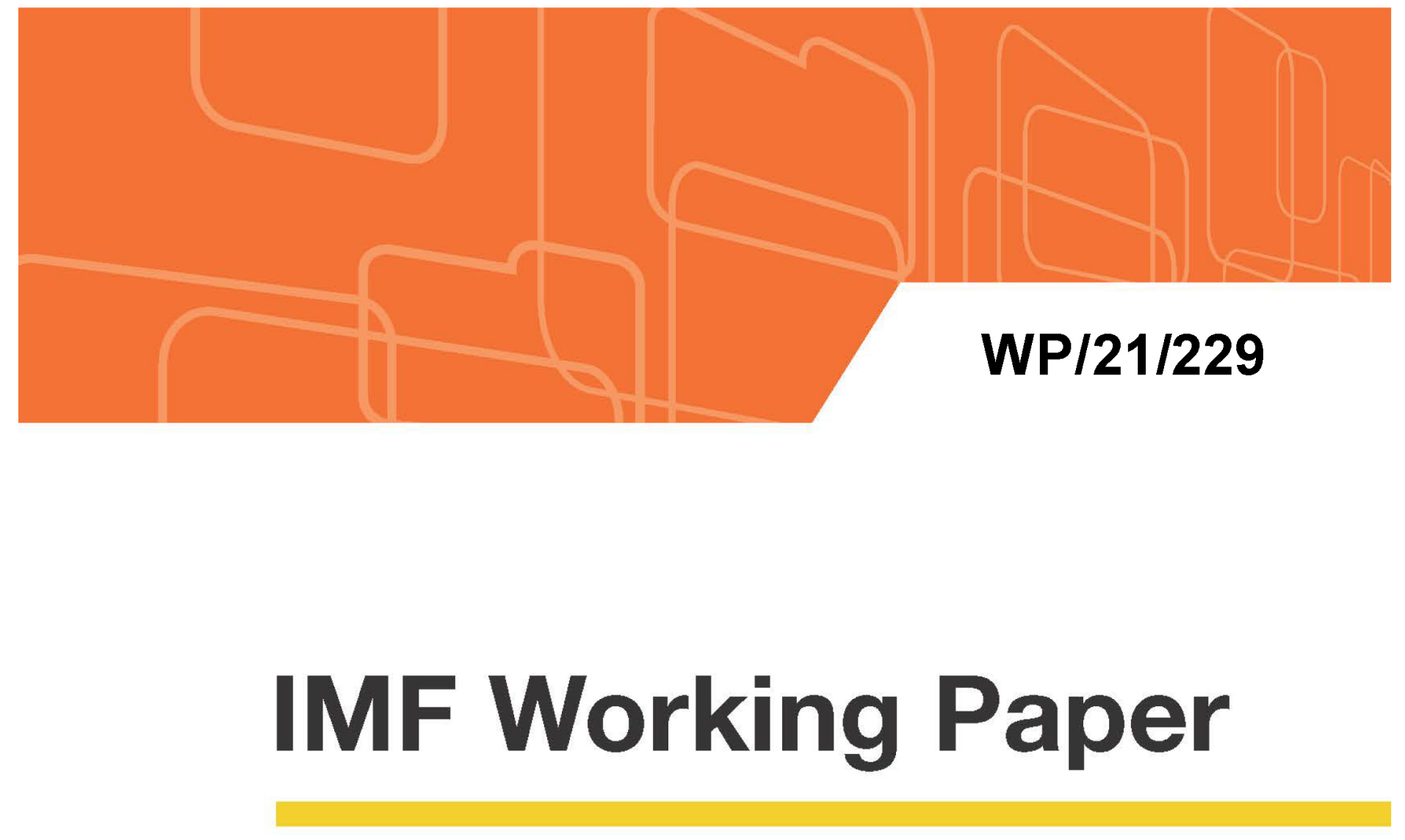

\title{
Debt Dynamics in Emerging and Developing Economies: Is R-G a Red Herring?
}

by Marialuz Moreno Badia, Juliana Gamboa Arbelaez, and Yuan Xiang

IMF Working Papers describe research in progress by the author(s) and are published to elicit comments and to encourage debate. The views expressed in IMF Working Papers are those of the author(s) and do not necessarily represent the views of the IMF, its Executive Board, or IMF management.

$$
\text { I N T E R N A T I O N A L M O N E T A R Y F U N D }
$$




\title{
IMF Working Paper
}

Fiscal Affairs Department

\author{
Debt Dynamics in Emerging and Developing Economies: Is R-G a Red Herring? \\ Prepared by Marialuz Moreno Badia, Juliana Gamboa Arbelaez, and Yuan Xiang \\ Authorized for distribution by Paulo Medas
}

September 2021

\begin{abstract}
IMF Working Papers describe research in progress by the author(s) and are published to elicit comments and to encourage debate. The views expressed in IMF Working Papers are those of the author(s) and do not necessarily represent the views of the IMF, its Executive Board, or IMF management.
\end{abstract}

\begin{abstract}
In the wake of the COVID-19 pandemic, debt levels in emerging and developing economies have surged raising concerns about fiscal sustainability. Historically, negative interestgrowth differentials in these countries have played a debt-stabilizing role. But is this enough to prevent countries from falling into debt distress? Drawing from a sample of 150 emerging and developing economies going back to the 1970s, we find that interest-growth differentials have remained relatively low, dampening debt increases in the run up to a crisis. But in the face of persistent primary deficits, debt service tends to rise abruptly — particularly in emerging markets - and a fiscal crisis ensues. There is also evidence that a large part of the debt build-up around crises stems from valuation effects associated with external debt and the materialization of contingent liabilities. These findings underscore that, though not necessarily a red-herring, low interest-growth differentials cannot fully offset the deleterious effects of large fiscal deficits, forex exposures, or hidden debts.
\end{abstract}

JEL Classification Numbers: E62, F34, H63

Keywords: debt, interest-growth differential, crisis, fiscal sustainability

Author's E-Mail Address: mmorenobadia@imf.org,gamboaa.juliana@gmail.com, YXiang@imf.org 
IV. ANATOMY OF INTEREST-GROWTH DIFFERENTIALS

A. Stylized Facts

B. Determinants of Interest-Growth Differentials

V. EXPLAINING DEBT DYNAMICS

A. Does r-g Matter? 15

B. Debt Dynamics Around Tail Events _ 16

C. The Changing Dynamics over the Course of a Crisis _ 20

VI. DETERMINANTS OF STOCK-FLOW ADJUSTMENTS_ 22

VII. CONCLUSIONS $\quad 23$

REFERENCES $\quad 25$

APPENDIX. DATA: DEFINITIONS AND SOURCES

FIGURES

1. Debt and Interest Expense in Emerging and Developing Economies

2. Interest-Growth Differentials in Emerging and Developing Economies__ 11

3. Share of Countries with Negative Interest-Growth Differentials___ 11

4. Persistence and Volatility of Interest-Growth Differentials__ 12

5. Real Interest Rates in Emerging and Developing Economies__ 13

6. Real Growth in Emerging and Developing Economies _ 13

7. Financial Openness in Emerging and Developing Economies___ 14

8. Debt Decomposition in Emerging and Developing Economies __ 17

9. Crisis Incidence in Emerging and Developing Economies__ 18

10. Macroeconomic Dynamics during Crisis Episodes _r 19

11. Debt Decomposition in EMDEs around Fiscal Crisis Episodes__ 21

12. Debt Dynamics around Fiscal Crisis by Duration _ 21

13. Debt Decomposition in EMEs around Fiscal Crisis Episodes__ 23

A.1.1. Country Coverage: Interest-Growth Differential __ 35

\section{TABLES}

1. Correlation between Real Interest Rate, Real Growth, and Real R-G__ 29

2. Determinants of the Interest-Growth Differential__ 30

3. Debt Decomposition by Income Groups and Decades___ 31

4. Fiscal Crises in EMDEs, 1970-2018_ 32

5. Determinants of Stock-Flow Adjustment _ 33 
APPENDIX TABLES

A.1.1. Country Classification

34

A.1.2. Variables: Definitions and Sources 


\section{INTRODUCTION ${ }^{1}$}

In the face of the worst global pandemic in over a century, fiscal deficits in emerging and developing economies (EMDEs) have ballooned, mainly reflecting an unprecedented collapse in revenues caused by the associated economic downturn. In the space of one-year, public debt has gone up by close to 10 percentage points of GDP in emerging market economies (EMEs) and by 5 percent in low-income developing countries (LIDCs). But, as stark as these increases are, they are just part of an upward drift that has been ongoing for more than a decade. As a result, current debt levels in EMDEs are now some 20-25 percentage points of GDP higher than those prevailing before the global financial crisis, sparking a debate about the sustainability of public finances. At one end of the argument there are concerns that, although debt is projected to stabilize to pre-pandemic levels over the next five years (Figure 1), it will remain woefully high (IMF 2021a). At the other-and notwithstanding financing constraints faced by EMDEs at the peak of the pandemic - the focus is on historically low interest payments. The main argument is that, once recovery is underway, interest rates are expected to remain below economic growth. In that view of the world, negative interest-growth differentials (henceforth, $r-g$ ) will continue to be the norm in EMDEs, buoying the sustainability of public debt. Implicitly, these are the assumptions in the IMF's World Economic Outlook.

Figure 1. Debt and Interest Expense in Emerging and Developing Economies

(Percent of GDP)

A. EMEs

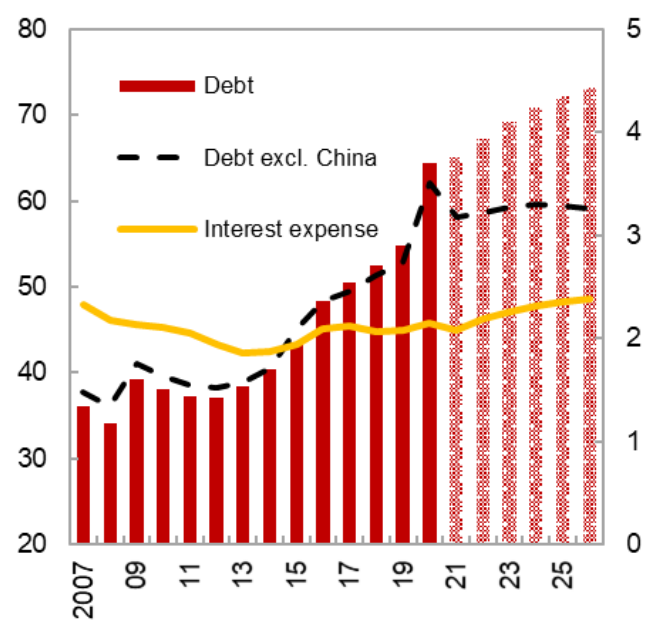

B. LIDCs

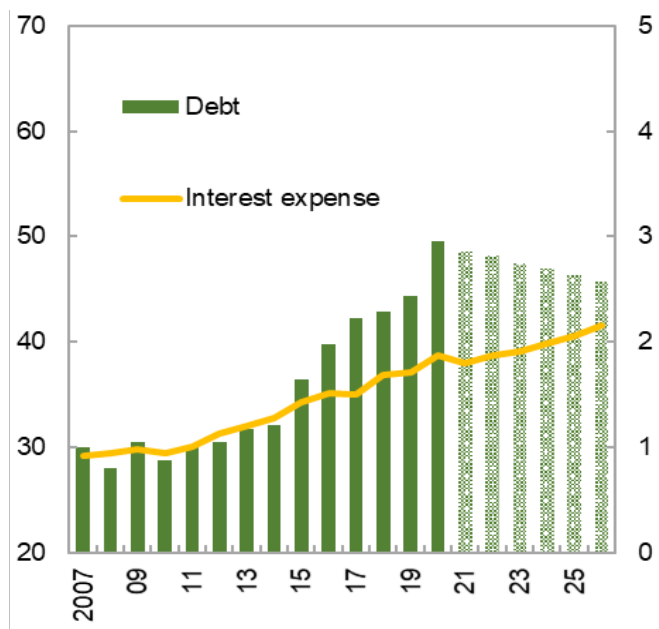

Source: IMF, World Economic Outlook (April 2021).

Notes: Debt aggregate for EMEs excludes Argentina, Lebanon, and Venezuela for which long-term projections are not available.

\footnotetext{
1 We gratefully acknowledge helpful suggestions by Santiago Acosta-Ormaechea, Zamid Aligishiev, Tamon Asonuma, Bas Bakker, Khalid Elfayoumi, Dennis Essers, Maximilien Kaffo, Samba Mbaye, Paulo Medas, Giovanni Melina, Ugo Panizza, Andrea Presbitero, Rossen Rozenov, Charles Wyplosz, Jeromin Zettelmeyer, participants of the May 2021 Workshop on Sovereign Debt and Development, and IMF colleagues.
} 
Predictably, given the unusually high degree of uncertainty at present, there is no consensus in academic circles as to whether the low $r-g$ is here to stay and could help prevent EMDEs from falling into debt distress (see Blanchard, Felman, and Subramanian 2021). In this paper, we look at that question from a slightly different angle: rather than venturing into forecasting what the future holds, we ask whether it actually matters that the $r-g$ is low. With that objective in mind, we examine the driving factors behind the debt dynamics in EMDEs. To fill the gap of previous studies, we use a more comprehensive dataset covering 150 EMDEs for the period 1971-2018 and ask three interrelated questions: (1) what are the empirical regularities on the $r-g$ and are there marked differences between EMEs and LIDCs?; (2) does the $r-g$ play a debt stabilizing role and does it make a significant difference during the various phases of a fiscal crisis?; and (3) are other factors more important in explaining debt dynamics in EMDEs? Our starting point is the standard debt decomposition equation (see, Escolano 2010). The main novelty of our empirical strategy is that we parse the data across various dimensions to tease out the qualitative and quantitative differences across disparate income levels, notably LIDCs-a group for which there was a big void in previous studies.

Based on this analysis, we are able to present a number of new facts. First, although negative over the last five decades, the average $r$ - $g$ has shown an upward drift as real interest rates have increased-more so in EMEs than in LIDCs. Results from an empirical model on the determinants of $r-g$ suggest that financial liberalization and the changing creditor profile (with less reliance on official and concessional financing) may partly explain these trends in EMEs. However, we do not find a robust relationship in the case of LIDCs, which is to a certain extent expected given the lower degree of financial development in those countries. What is particularly important for this income group are the changes in public debt, with larger increases leading to a higher $r-g$.

Second, the $r$ - $g$ has played a debt stabilizing role over the last five decades, although to a much lesser degree in EMEs than in LIDCs. However, the low $r-g$ has not been able to stymie the accumulation of debt in EMDEs in recent years. This is the reflection of large primary deficits and the so-called stock-flow adjustments - which measure valuation effects and the materialization of contingent liabilities (or what is often called "hidden debts"). Remarkably, this trend is even more pronounced when looking at tail events. In particular, the $r-g$ remains relatively low in the run-up to a crisis, putting some restraint on public debt. But in the face of persistent primary deficits, debt service tends to rise abruptly in EMEs, and a fiscal crisis ensues. The dynamics of primary deficits are similar in LIDCs although the orders of magnitude are smaller.

Third, one of the most important trademarks of fiscal crises in EMDEs is the accumulation of stock-flow adjustments which is always a big part of the story in the entry phase of a crisis. Valuation effects associated with foreign exchange debt and the depreciation of the currency appears to be the most important factor behind these stock flows. But there is also some evidence that the materialization of contingent liabilities associated with the private sector may be playing a role in EMEs. At the same time, the exit out of a crisis generally entails a reversal of sorts. Primary deficits usually turn into surpluses, and stock-flow adjustments become negligible. What is notable is that there are not significant differences in the $r$ - $g$ getting in and out of the crisis. 
To sum up, the large shifts in debt ratios among EMDEs over the last fifty years cannot be entirely explained by developments in the $r$ - $g$. Rather, the underlying trends in the primary deficits, valuation effects, and the realization of contingent liabilities have been more important determinants particularly in times of distress. This is not to say that changes in the $r-g$ do not have any bearing. A sudden rise in interest rates relative to growth could result in explosive debt dynamics, particularly if debt ratios are high and gross financing needs large. But what this paper illustrates is that, even if the $r$ - $g$ is negative, it can not necessarily prevent cliff-like events.

\section{Related Literature}

This paper aims at contributing to two strands of the literature. First, our analysis is related to the increasing number of studies that have examined the dynamics of $r-g$. Most of this research has focused on advanced economies examining historical interest-growth differentials and documenting how they are usually negative in these countries (Barrett 2018)-particularly if the interest rate if gauged by the real rate of return of short-term government bills (Barro 2020). Low inflation volatility and accommodative monetary policy are important factors explaining these trends in recent years (Turner and Spinelli 2011). Not surprisingly given the dearth of data, only in a few cases have researchers looked into EMDEs, primarily analyzing the determinants of $r-g$ and/or their predictive power in early warning models (Escolano, Shabunina, and Woo 2017; Lian, Presbitero, and Wiriadinat 2020; and Mauro and Zhou 2021). The main finding of these studies is that the low $r-g$ in EMDEs is often explained by negative real interest rates stemming from financial repression. At the same time, the $r-g$ tends to spike only at the onset of a crisis, making it a poor leading indicator of sovereign default (Moreno Badia et al. 2020).

A related and somewhat more voluminous research has focused on the determinants of interest rates in EMEs. ${ }^{2} \mathrm{~A}$ large part of that literature identifies fiscal indicators-such as government deficits and debt levels - as being highly correlated with sovereign spreads (Alexopoulou, Bunda, and Ferrando 2010; Baldacci and Kummar 2010). The composition of debt, however, matters. In particular, some papers find that the correlation between debt and spreads is high and statistically significant only for those EMEs with a large share of debt denominated in foreign currency (Dell'Erba, Hausmann, and Panizza 2013). Countries with stronger fundamentals tend to have lower sensitivity to changes in global risk aversion (Csontó and Ivaschenko, 2013). However, domestic bond yields are mostly influenced by inflation and real GDP growth expectations and not by fiscal variables when global risk aversion is low (Jaramillo and Weber 2013). More importantly, there is evidence that EMEs remain vulnerable to sudden shifts in global financial conditions, notwithstanding improvements in macroeconomic policy and fundamentals over the last few decades (Hartelius, Kashiwase and Kodres 2008; Ciarlone, Piselli and Trebeschi 2009; Csontó 2014; and Miyayima, Mohanty and Chan 2015).

Relative to that literature, our contribution is twofold. First, to the best of our knowledge, this is the first study to analyze systematically trends and differences in the $r$ - $g$ of EMEs versus LIDCs thanks to a more comprehensive dataset. Second, in explaining the determinants of the $r-g$, we move beyond standard indicators of financial repression, global factors, and currency

\footnotetext{
${ }^{2}$ Not much analysis has been done on LIDCs given that most of these countries do not have market access and for those that do it is a relativelynew phenomenon.
} 
composition of debt and consider in addition the creditor profile-an important factor given the changing financing landscape among EMDEs.

Our analysis also relates to a second strand of the literature linking debt dynamics to the $r-g$. A large body of that work focuses on debt sustainability, characterizing the conditions under which solvency is assured. For example, Bohn (1998) shows that the government's intertemporal budget constraint holds if the primary balance reacts positively to lagged debt, although this entails that public debt ratios could potentially rise indefinitely. The response of fiscal policy, however, may be endogenous to the $r$ - $g$, with increases in sovereign borrowing costs leading to a stronger policy response to debt changes than declines in growth (Mauro et al. 2015). Ghosh et al. (2013), on the other hand, show that once that there is a possibility of fiscal fatigue-whereby the primary balance responds more slowly to rising debt than the $r-g$-there is a debt limit beyond which debt dynamics become explosive and sovereign default is unavoidable. By contrast, Blanchard (2019) provides evidence that the fiscal and welfare costs of public debt may be very small if $r$ - $g$ is negative, though these conclusions may not hold under different parametrization (Evans 2020; Hasanhodzic 2020; Mehrotra and Sergeyev 2020), or if investors believe that debt is risky triggering a self-fulfilling crisis. By and large, this literature is mainly centered on advanced economies, thereby ignoring important factors in determining the sustainability of public debt in EMDEs such as rollover risks or the possible realization of contingent liabilities (Buysse, De Sloover, and Essers 2021; IMF 2021b). In fact, a few empirical studies looking at EMDEs identify stock-flow adjustments as one of the main sources of debt spikes (Campos, Jaimovich, Panizza 2006; Abbas, Belhocine, El-Ganainy, and Horton 2011), more so than primary deficits or growth slowdowns (Jaramillo, Mulas Granados, and Kimani 2017). Another important factor in explaining fiscal sustainability in EMDEs is the currency composition of debt (Taddei and Panizza 2020).

What all these studies point to is that debt sustainability depends on a broad range of factors of which the $r-g$ is just one. Our paper takes and empirical approach expanding on these works across several dimensions. First, we explicitly compare debt dynamics in EMEs and LIDCs (the latter group is often omitted in previous work), considering not just the $r-g$ but also all other determinants. Our focus is not only on the debt dynamics during normal times but also during crisis episodes and at different points of the debt distribution. Second, our analytical approach distinguishes between the various phases of a fiscal crisis, as well as the typology of a crisis. And third, we make some inroads in exploring the nature of below the line operations in EMDEs.

The remainder of the paper is organized as follows. Section II describes the data and provides an overview of the methodological issues regarding the measurement of valuation and contingent liabilities. The next section compares the dynamics of the interest-growth differentials in EMEs and LIDCs, exploring whether the nature of borrowing and the degree of financial openness may explain differences across them. Section IV explores the debt dynamics in EMDEs, identifying some distinctive features around tail events. Section $V$ zeros in on the stock-flow adjustments and examines the relative importance of the forex exposures and contingent liabilities. Section $\mathrm{VI}$ provides some concluding thoughts. 


\section{DATA}

This paper draws from a dataset of fiscal, macroeconomic, and crisis variables covering an unbalanced panel of 150 EMDEs for the period 1971-2018 (Moreno Badia et al. 2020, updated up to 2018). The sample includes 92 EMEs and 58 LIDCs with data coverage improving gradually over time and accounting for 90 percent of GDP in EMDEs by the mid-1990s. The dataset has been supplemented with data on the external debt composition by creditor type, external debt guarantees, and an index of financial account liberalization. Appendix 1 discusses definitions and sources in more detail.

As with any studies on EMDEs, data availability and quality are important constraints. Two methodological issues are particularly worth noting from that perspective:

- Valuation effects. Information on the currency composition of debt, necessary to calculate the revaluation impact of exchange rate depreciation on public debt, is patchy. Inevitably, one has to strike a balance between the country/time coverage and a consistent conceptual coverage. On the one hand, the IMF's World Economic Outlook dataset includes data on foreign-currency denominated debt but time series, when available, are typically short. ${ }^{3} \mathrm{An}$ alternative data source is the World Bank's International Debt Statistics (IDS) which reports external general government debt excluding guarantees for a broad set of EMDEs going back to the 1970s. However, these data come with some drawbacks. First, the definition of external debt in IDS is based on a residency concept (i.e., nationality of the creditor) which can lead to over-estimating the share of foreign-currency debt to the extent that external creditors hold domestic-currency debt. This is, however, unlike to be a big issue for the majority of countries in our sample. ${ }^{4}$ Second, the external debt aggregate excludes short-term maturities, therefore underestimating the size of foreign claims. And third, the perimeter of government for the IDS's external debt data may not coincide with that of public debt data which come from the Global Debt Database-the latter refers in many instances to the central government debt while the former refers to the general government. In this paper, we take a pragmatic approach giving preference to the consistent measurement of debt aggregates throughout time. This means that for each country we choose the dataset for which we have better coverage, which in two thirds of cases is the IDS. Following Panizza and Teddei (2020), we cap the share of public external debt at 100 percent for those cases in which the government perimeter of external debt is broader than that of public debt.

- Contingent liabilities. Databases on the materialization of contingent liabilities are scant. The most comprehensive source is Bova et al. (2019) but the coverage is limited to 44 EMDEs (only one of which is a LIDC) and the period 1990-2014. This would imply excluding from our analysis a large number of countries (notably, most low-income) and crisis episodes particularly in the 1980s. We instead look at variables that could potentially be correlated

\footnotetext{
3 The World Bank's Quarterly Public Sector Debt (QPSD) database also reports the currency composition of public debt, but time series often start in 2008 or thereafter.

${ }^{4}$ Although in some countries (such as Brazil) there is an increasing presence of foreign creditors in domestic currency markets (Sabbadini 2018), the empirical evidence suggests that investors tend to underweight bonds not denominated in their own currency in their portfolio decisions (Burger, Warnock, and Warnock 2018).
} 
with the realization of contingent liabilities and for which data are more widely available. First, an extensive literature has established large spillovers from private sector debt overhangs-which are often accompanied by financial crises-into the public sector (see, Mbaye, Moreno Badia, Chae 2018a; and Reinhart and Rogoff 2009 and 2013). To capture this facet, we look not only at private credit but also at publicly guaranteed external private debt. Second, governments have in the past provided significant support to state-owned enterprises predominantly recapitalizations and debt assumptions with significant budgetary impact (IMF 2020). To proxy for this channel, we look at the external debt of the other public sector (outside the general government). ${ }^{5}$ Though by no means these are the only potential sources of contingent liabilities, they are the most common and largest source of shocks to the public sector balance sheet (see, IMF 2016).

\section{ANATOMY OF INTEREST-GROWTH DifFERENTIALS}

Before diving into the debt dynamics, we begin by providing an overview of the interest-growth differentials (henceforth, $r-g$ ) in EMDEs, considering their evolution across time and country groups. In line with the debt dynamics equation (see, Escolano 2010), the $r-g$ in period $t$ is measured as $\frac{i_{t}-\gamma_{t}}{1+\gamma_{t}}$, where $\left(i_{t}\right)$ is the effective interest rate on debt and $\left(\gamma_{t}\right)$ is the nominal GDP growth rate. The effective interest rate is, in turn, calculated as the ratio of the interest bill in year $t$ to the stock of government debt (measured as the average of the debt stock in year $t$ and $t-1) .{ }^{6}$

\section{A. Stylized Facts}

On average, the $r-g$ has been negative for both EMEs and LIDCs since the early 1970s with the exception of 2009-when EMEs displayed a positive $r$ - $g$ reflecting the contraction of output in the midst of the global financial crisis-and 2015 when oil producers saw a marked slowdown in growth. ${ }^{7}$ However, there are significant differences within and across country groups:

- Levels. The $r-g$ has been on average $-81 / 2$ percent in EMEs and $-91 / 2$ in LIDCs over the full sample period (Figure 2). The gap between the two income groups reached a peak in 2009, when the $r-g$ increased by more than 15 percentage points in EMEs, going into positive territory for the first time in nearly four decades. By contrast, although LIDCs also experienced an uptick in 2009, the average $r$ - $g$ remained well into negative territory. Reflecting the short-lived nature of the recession in EMEs, part of the surge in the $r-g$ was reversed. Nonetheless, compared to the earlier years, the difference between the two country groups has widened after the global financial crisis with the average $r-g$ in LIDCs more than 4 percentage points below EMEs in 2018.

\footnotetext{
${ }^{5}$ The most wide-ranging database on public sector balance sheets is Alves, de Clerck and Gamboa Arbelaez (2020) but it only includes 23 EMDEs for the years 2000-16 and it does not disentangle the liabilities across different levels of government.

${ }^{6}$ Due to data constraints, we cannot disaggregate the interest bill between domestic and foreign currency debt, so implicitly valuation effects associated with exchange rate fluctuations are not accounted for. This could underestimate the size of the $r$ - $g$ in periods of stress (see, Acosta-Ormaechea 2020).

${ }^{7}$ The most recent estimates from the World Economic Outlook suggest that the average $r-g$ also turned positive for both EMEs and LIDCs in 2020 amid the global output collapse following the COVID-19 outbreak.
} 
- $\quad$ Trend. Although on average 80 percent of EMEs and 90 percent of LIDCs had negative $r-g$ over the sample period, there have been big swings at specific points in time, notably in the mid-1980s and 1990s, early 2000s, and 2009 (Figure 3). Interestingly, the fluctuations in the average $r-g$ appear to have become synchronized across country groups after the global financial crisis: the correlation between EMEs and LIDCs is 0.54 for the full sample and 0.98 from 2010. Also, there has been an upward drift in both income groups although of different orders of magnitude: over the last fifty years, the average $r-g$ has increased by about 31/2 percentage points in EMEs but only by 1 percentage points in LIDCs. Nonetheless, a close look at the distribution of $r$ - $g$ reveals that the compression in the interquartile range has moved in parallel for both country groups: from an average of about 11 percentage points prior to the global financial crisis to about $6 \frac{1}{2}$ percentage points thereafter.

Figure 2. Interest-Growth Differentials in Emerging and Developing Economies (Percent)

A. EMEs

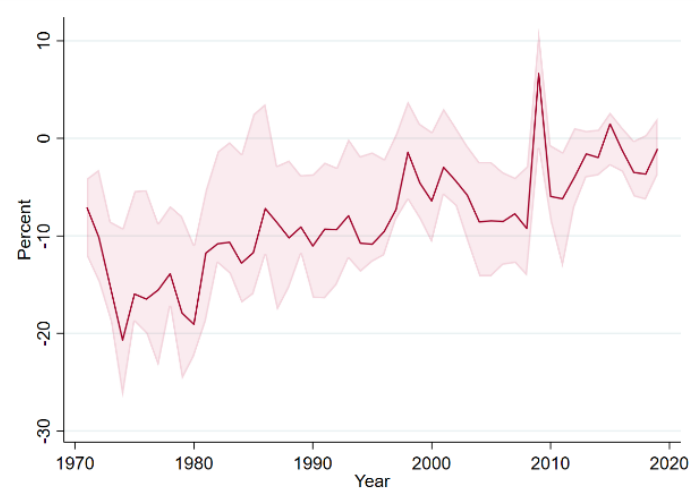

B. LIDCs

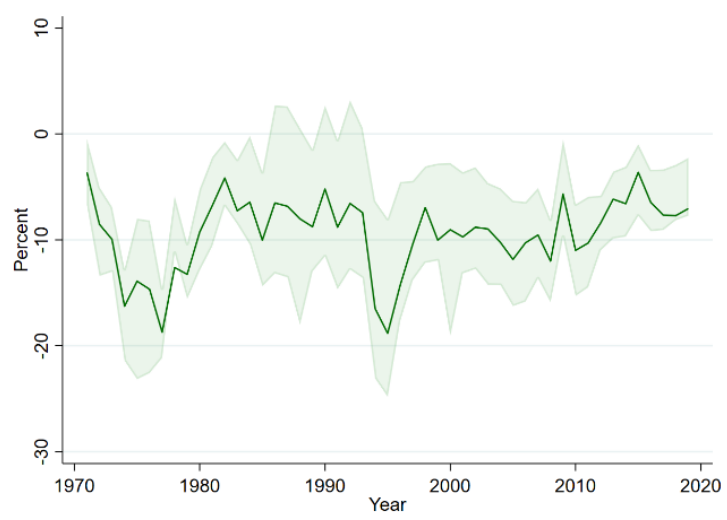

Sources: IMF, World Economic Outlook; Mbaye, Moreno Badia, and Chae (2018b); and authors' calculations. Notes: Shaded area correspond to the interquartile range.

Figure 3. Share of Countries with Negative Interest-Growth Differentials (Percent)

A. EMEs

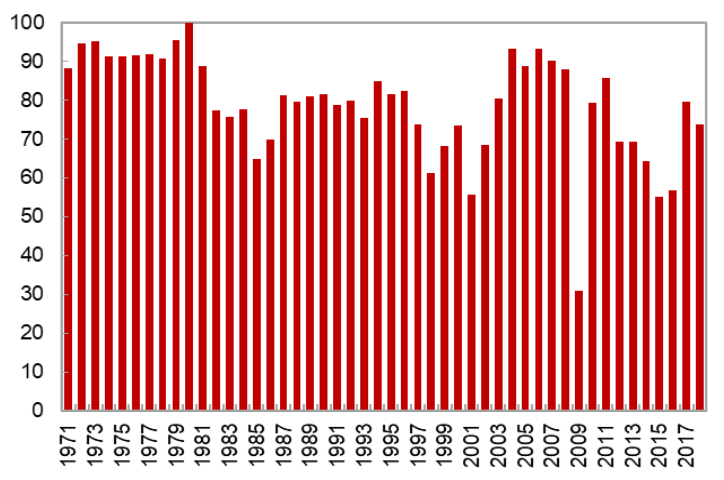

B. LIDCs

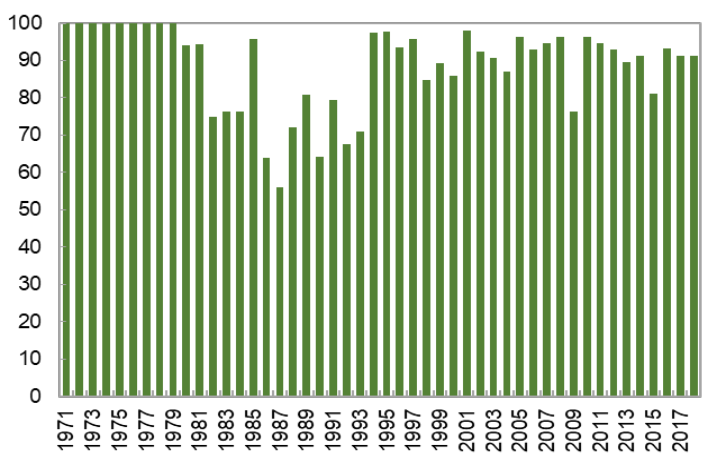

Sources: IMF, World Economic Outlook; Mbaye, Moreno Badia, and Chae (2018b); and authors' calculations. 
- Volatility and persistence. Both country groups also display high degree of volatility. On average, the within-country standard deviation of the $r-g$ is about 10 percentage points for the entire sample for both groups. However, the decline in volatility post global financial crisis has been more pronounced in EMEs than in LIDCs (Figure 4). Relatedly, persistence as measured by first-order autocorrelation AR(1) coefficient is very low, ranging from 0.3 to 0.4 on average. These features provide a cautionary tale about favorable $r$ - $g$ in EMDEs - they do not last forever-pointing to the boom and bust cycles typical of debt crises that often lead to abrupt increases in interest rates and sharp output declines, an issue to which we will return in the next section.

\section{Figure 4. Persistence and Volatility of Interest-Growth Differentials}

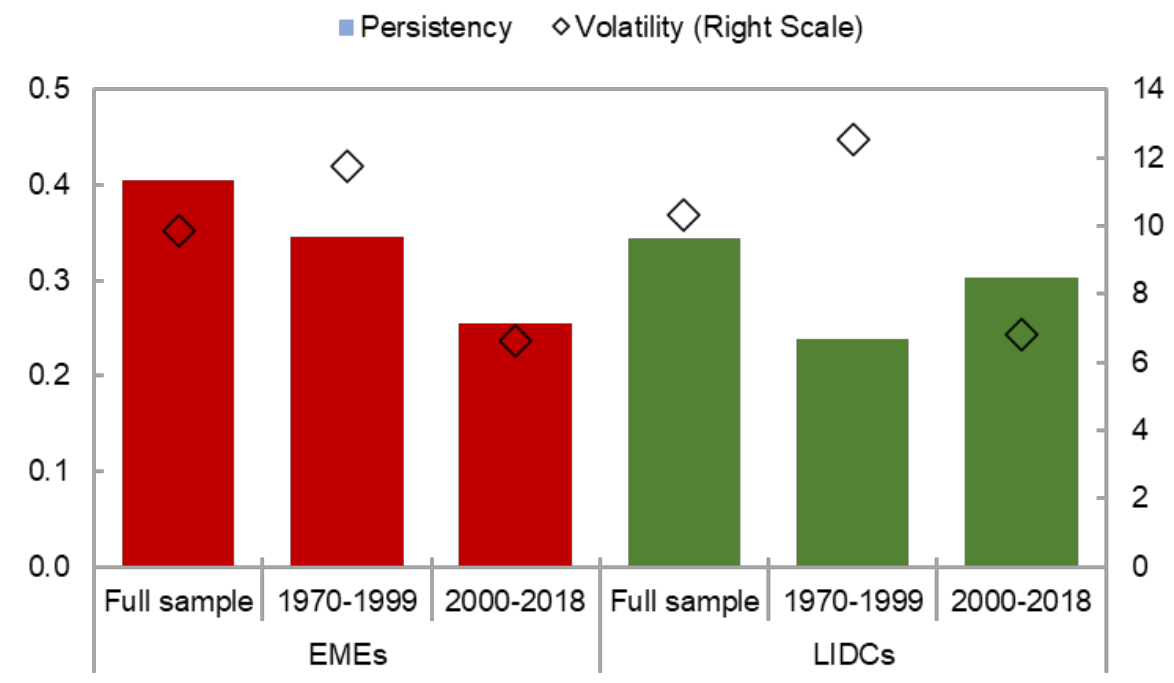

Sources: IMF, World Economic Outlook; Mbaye, Moreno Badia, and Chae (2018b); and authors' calculations. Notes: The volatility is measured by the standard deviation of the $r-g$ in each country. The persistence is measured by the first-order autoregressive AR(1) coefficient.

\section{B. Determinants of Interest-Growth Differentials}

We now turn to the factors explaining the evolution of $r$ - $g$ over time. To a large extent, the literature has argued that $r-g$ has remained in negative territory in EMDEs for long stretches thanks to real interest rates well below market rates. The main explanation provided in recent studies is that financial repression and distorted markets have prevented the rise in nominal interest rates in the face of increasing inflation (Escolano, Shabunina, and Woo 2017; and Mauro and Zhou 2021). This suggests that the income catch-up process may have played a relatively modest role. A cursory look at the data reveals that:

(1) Real interest rates have indeed been negative for most of the sample. However, inflation has fallen much quicker than the nominal effective interest rates over the last fifty years, pushing real interest rates up in both income groups (Figure 5). Nonetheless, the increase has been more pronounced among EMEs where on average real rates have been close to zero after the global financial crisis. 
(2) Real growth rates, on the other hand, have been marginally higher on EMEs than LIDCs over the full sample period ( $33 / 4$ and $31 / 2$ percent respectively). Although in both cases they have exhibited a downward trend, the orders of magnitude are very different. Since the 1970s, real growth has come down by 31/4 percentage points in EMEs but only by about $1 / 2$ percentage point in LIDCs (Figure 6). ${ }^{8}$

Figure 5. Real Interest Rates in Emerging and Developing Economies

A. EMEs

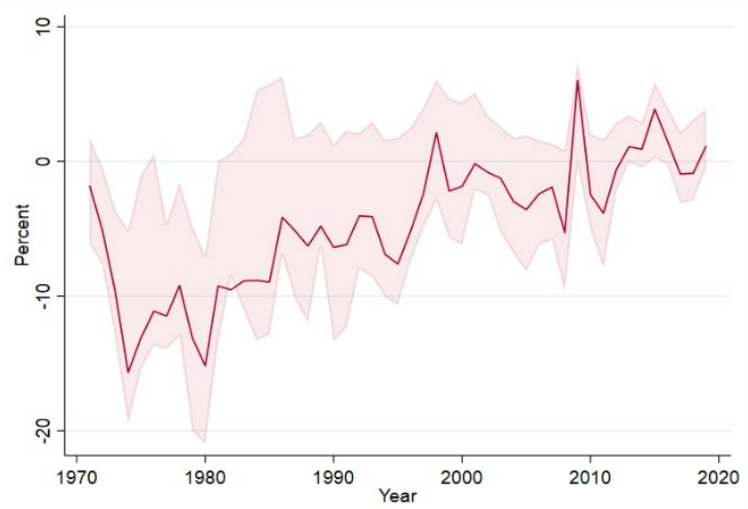

B. LIDCs

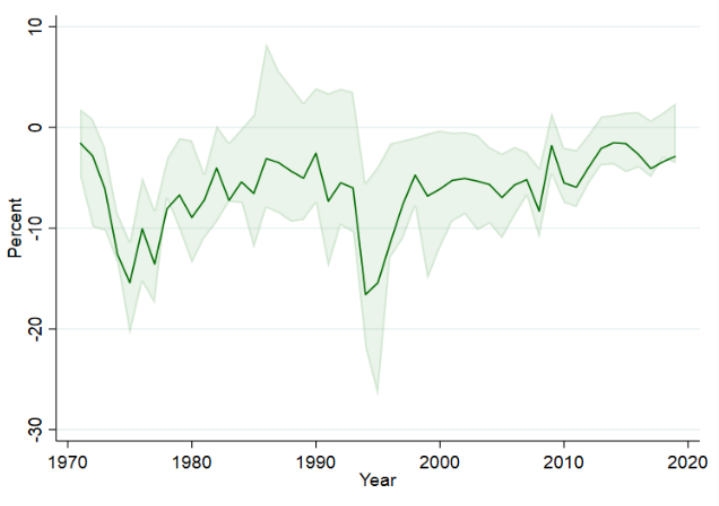

Sources: IMF, World Economic Outlook; Mbaye, Moreno Badia, and Chae (2018b); and authors' calculations. Notes: Nominal effective interest rate is deflated using the GDP deflator.Shaded area corresponds to the interquartile range.

Figure 6. Real Growth in Emerging and Developing Economies

A. EMEs

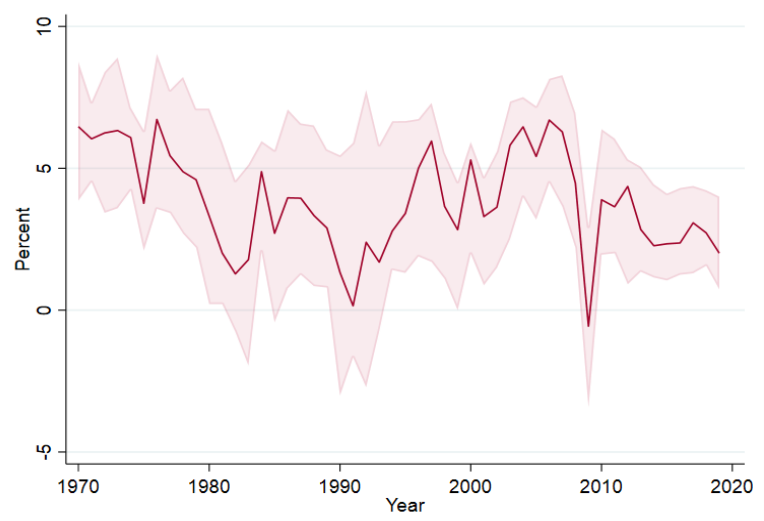

B. LIDCs

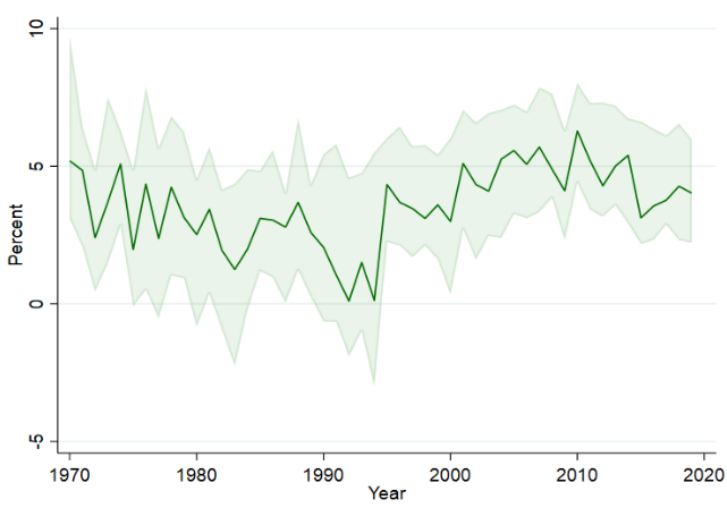

Sources: IMF, World Economic Outlook ; and authors' calculations.

Notes: Shaded area corresponds to the interquartile range.

The correlation of the real interest rates with the $r$ - $g$, at about 0.9 for both country groups, implies that the real interest rate may be the most important driver (Table 1). Just as a comparison, the correlation of growth and the $r-g$ is a mere 0.1 for the full sample. The trends

\footnotetext{
${ }^{8}$ Growth in LIDCs have not followed a lineartrend. In particular, the 1980s and 1990s showed a sharp fall in growth rates that was only reversed in the 2000 s.
} 
outlined above, however, indicate a reversal of sorts may be starting to play out. Zeroing in on the period after the global financial crisis, it appears that the correlation of the real interest rate with the $r-g$ has been reduced while that of real growth has gone up, particularly for EMEs. A possible explanation is that these economies may have become less financially repressed in recent years and, thus, income convergence (and growth) may be gaining importance. From that perspective, it is illustrative to look at the financial openness index of Chinn and Ito (2006) since 1970. Although, an imperfect measure of financial repression, this index gives an idea of the existence of capital controls which is often a pre-requisite for captive saving markets and interest rate controls. Overall, the improvement in financial openness has been more marked in EMEs than in LIDCs where the trend has been pretty flat since the early 2000s (Figure 7). This suggests that financial repression may be a more important factor among EMEs. Going beyond financial repression, another possible contributor to explain recent changes in $r-g$ is the more diversified creditor and borrowing profile. In particular, the official sector has become a less important creditor for EMEs where it currently accounts for 56 percent of external public debt. In contrast, although declining, official debt still represents 85 percent of public external debt in LIDCs. More significant is the decline in the share of concessional borrowing, which has been reduced by half from its peak, reaching 13 and 33 percent of external public debt in 2018 for EMEs and LIDCs respectively. To the extent the switch in the debt composition may have resulted in higher borrowing costs, it would have also led to a higher $r-g$.

\section{Figure 7. Financial Openness in Emerging and Developing Economies}

A. EMEs

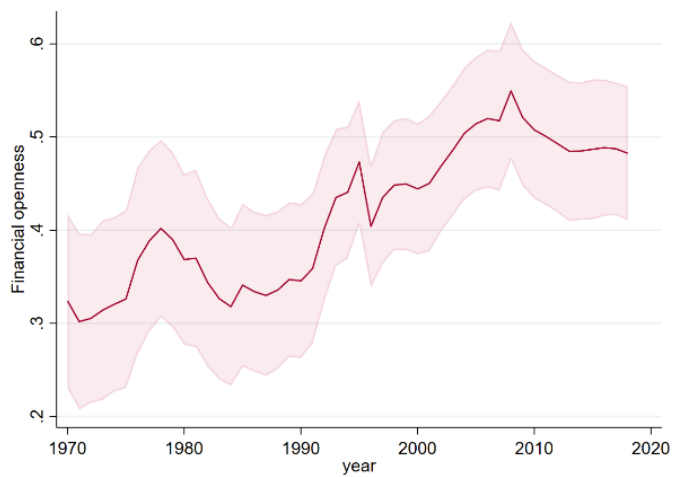

B. LIDCs

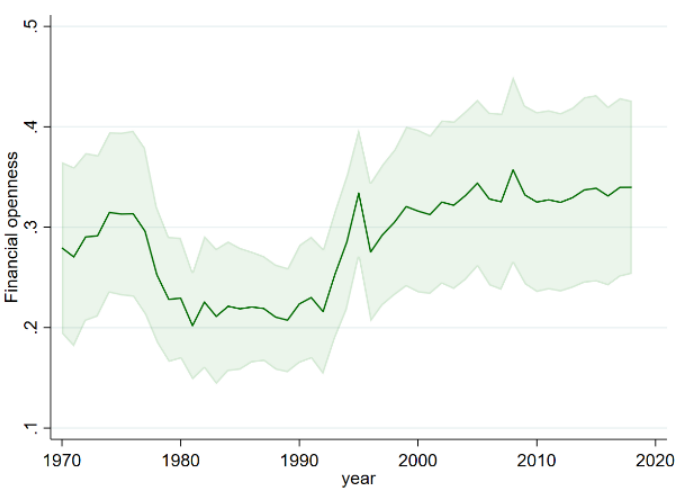

Sources: Chinn and Ito (2006); and authors' calculations. Notes: Shaded area corresponds to the $95 \%$ confidence interval.

Following Mauro and Zhou (2021), we estimate a fixed effects model of the $r-g$ to explore the relative importance of these factors. The baseline specification is as follows:

$$
(r-g)_{t}=\beta_{1} F O_{i t}+\Gamma X_{i t}+\alpha_{i}+\epsilon_{i t}
$$

where $\mathrm{FO}_{i t}$ is the continuous financial openness indicator in country $i$ and period $t$ taken from Chinn and Ito (2006); $X$ is a vector of variables including the lagged real interest rate (for serial correlation), lagged real growth (for cyclical conditions), the change in public debt and initial public debt (for fiscal conditions), the share of official and concessional public external debt (for debt composition), expected inflation as proxied by lagged inflation rate, exchange rate depreciation (to account for any valuation effects), private debt (as a proxy for financial 
deepening), commodity prices and VIX index (for global shocks and risks), and a HIPC dummy for the years between decision and completion points (to capture the debt relief associated with the HIPC initiative); $\alpha_{i}$ are country fixed effects, and $\epsilon_{i t}$ is the error term.

Overall, financial openness is positively associated with the $r-g$ only for EMEs, suggesting that financial repression may have suppressed the increases in nominal rates in response to higher inflation and graduation from it may have led to the opposite effect (Table 2). It is not surprising, however, that we do not find a similar effect in LIDCs given that financial liberalization in these countries have been more muted. Debt composition seems to matter for EMEs as well: higher official and concessional debt are associated with lower $r-g$ and as expected the impact of the latter is much higher. ${ }^{9}$ Surprisingly, when it comes to LIDCs the debt composition is not driving the changes of $r-g$ although nominal effective interest rates do show a negative association with the share of official debt. Instead, the changes in public debt-increases leading to higher $r-g-$ are much more important. To further determine the relative importance of the independent variables, we conduct a dominance analysis based on contributions to overall model fit. ${ }^{10}$ The last two rows of Table 2 confirm that real interest rates have indeed a much higher explanatory value than real growth rates for both EMEs and LIDCs irrespective of the model specification and consistent with previous studies (Escolano, Shabunina, and Woo 2017).

\section{EXPLAINING DEBT DYNAMICS}

\section{A. Does r-g Matter?}

We have shown thus far that negative interest-growth differentials have been the norm among EMDEs for the last fifty years. The question we try to address in this section is whether this has made much of a difference on debt dynamics. Our starting point is the standard decomposition of debt changes:

$$
d_{T}-d_{0}=\sum_{t=1}^{T} \frac{i_{t}-\gamma_{t}}{1+\gamma_{t}} d_{t-1}+\sum_{t=1}^{T} p_{t}+\sum_{t=1}^{T} s f a_{t}
$$

where the change in the debt-to-GDP ratio over the period of interest $\left(d_{T}-d_{0}\right)$ is the sum of three components: (1) the product of the lagged debt ratio and the differential between the effective interest rate on debt $\left(i_{t}\right)$ and the nominal GDP growth rate $\left(\gamma_{t}\right)$, cumulated over the period; (2) the cumulative primary deficit $\left(p_{t}\right)$; and (3) a cumulative residual stock-flow adjustment $\left(s f a_{t}\right)$ capturing different factors, including valuation effects, below-the line operations (such as financial sector recapitalization, privatization, and transactions in financial assets), and errors and omissions.

\footnotetext{
${ }^{9}$ Similar results are obtained if controlling for public external debt instead of official and concessional debt.

${ }^{10}$ Dominance analysis is conducted using the stata command "domin". For more details on the statistical properties, see Grömping (2007).
} 
Table 3 shows the contributions to average annual debt changes of these three components. ${ }^{11}$ Two types of comparison, across income groups and across time, interest us motivated by two questions: does the relative importance of $r$ - $g$ differ between EMEs and LIDCs?; and do we see a decline in the contribution of $r-g$ over time? On the first question, we find that $r-g$ has contributed to reducing debt in both EMEs and LIDCs: on average $23 / 4$ percentage points of GDP per year in EMEs and about 51/2 in LIDCs. In tandem, average primary deficits and stock-flow adjustments in LIDCs have been significantly higher than in EMEs over the full sample period. But while the $r-g$ has more than offset these forces in LIDCs driving debt down, that has not been the case in EMEs. ${ }^{12}$ By decades, however, the picture that emerges is a bit more complex. In EMEs, the contributions of $r-g$ to debt dynamics have been negative but declining throughout. In contrast, the negative contribution of the $r-g$ to debt dynamics widened in the 1990s and 2000s for the average LIDC but started to decline after the global financial crisis. An interesting development is that primary deficits, which had initially narrowed in the 2000s, went up in both EMEs and LIDCs over the following decade. The increase in primary deficits, coupled with a less favorable $r$ - $g$ and positive stock-flow adjustments, ultimately contributed to average debt increases in the range of 1.2 to 1.4 percent of GDP per annum since 2010.

To sum up, the negative $r-g$ has played a debt stabilizing role over the last five decades, although to a much lesser degree in EMEs than in LIDCs. ${ }^{13}$ However, that dampening effect has declined over time, and in recent years has not been enough to make up for increasing primary deficits and positive stock-flow adjustments. In what follows, we argue that these trends are even more striking when looking at tail events.

\section{B. Debt Dynamics Around Tail Events}

We first focus on the $75^{\text {th }}$ percentile of the distribution which shows annual debt increases $71 / 2$ and $103 / 4$ percentage points of GDP above the average in EMEs and LIDCs respectively. Figure 8 plots the debt decomposition and highlights how these spikes are largely explained by factors other than the $r-g$. In particular, what sets these extreme events apart are the stock-flow adjustments which amount to 7 percent of GDP in EMEs and 113/4 percent of GDP in LIDCs. Although a counterbalancing force, the $r-g$ contribution is less than half that size, consistent with previous findings in the literature (see, for example, Weber 2012).

\footnotetext{
${ }^{11}$ A positive number means that the component is contributing to an increase in debt. The term $r$ refers to $\frac{i_{t}}{1+\gamma_{t}} d_{t-1}$, while the term $g$ refers to $-\frac{\gamma_{t}}{1+\gamma_{t}} d_{t-1}$, and SFA to the stock-flow adjustment

${ }^{12}$ This confirms that a negative $r$ - $g$ does not preclude an outcome in which the required primary balances to stabilize debt are large and, unable to adjust, governments continue running deficits and debt goes up. These dynamics, however, can only go on as long as financing is available.

${ }^{13} \mathrm{~A}$ possible reinforcing channel for the negative $r-g$ to have a debt stabilizing role is the fact that fiscal multipliers may be higher in those instances (see, Di Serio, Fragetta, and Melina 2021).
} 
Figure 8. Debt Decomposition in Emerging and Developing Economies

(Percent of GDP)

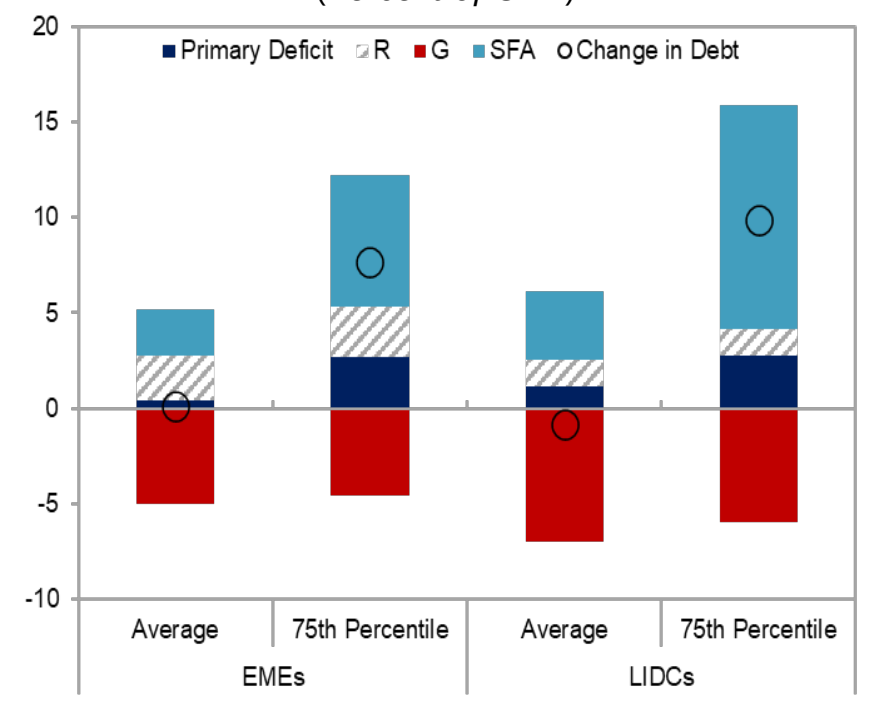

Source: Authors' calculations.

Notes: Reported numbers are the average annual changes of debt and contributions. A positive number means that particular component is contributing to an increase in debt. The term R refers to $\frac{i_{t}}{1+\gamma_{t}} d_{t-1}$, while the term G refers to $-\frac{\gamma_{t}}{1+\gamma_{t}} d_{t-1}$, and the SFA is the stock-flow ajdumstment. The $75^{\text {th }}$ percentile refers to the distribution of the changes in debt. Observations at the top or bottom 1st percentile based on debt change are excluded.

To better understand the role of the $r$ - $g$, we turn to analyze the debt dynamics during periods of heightened budgetary distress or what is commonly called a "fiscal crisis". These episodes may result in a credit event (i.e., sovereign default or restructuring), exceptionally large official financing, implicit domestic debt default, and/or loss of market confidence (Medas et al. 2018). We start by providing an overview of the defining characteristics of these crises in EMDEs. Since 1970, there have been 220 fiscal crisis episodes in EMEs and 214 in LIDCs with an average duration of 5-6 years (Table 4). The large majority of episodes are associated with credit events. In general, fiscal crises are more persistent in LIDCs where in close to one third of cases a crisis starts within three years of the end of the previous one. This suggests that crises are protracted episodes that may not be resolved in one-go, consistent with the idea of serial defaults resulting from interim restructurings that fall short of placing debt on a sustainable path (Reinhart, Rogoff, and Savastano 2003; and Graf von Luckner et al. 2021). In addition, crises tend to come in waves. The peak was in the mid-1990s when about 50 percent of EMEs and 80 percent of LIDCs were in a fiscal crisis (Figure 9). 


\section{Figure 9. Crisis Incidence in Emerging and Developing Economies}

A. EMEs

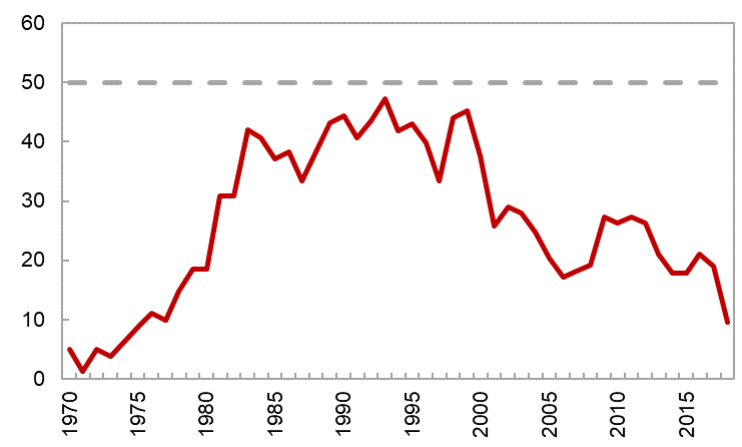

B. LIDCs

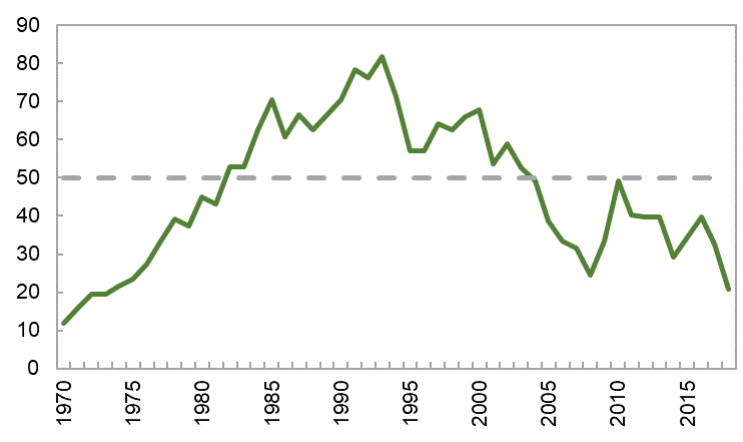

Sources: Moreno Badia et al. (2020); and authors' calculations.

Notes: The chart plots for each year the percentage of countries in fiscal crisis.

To characterize what drives debt dynamics around crises, we first examine the behavior of the primary balance, $r$ - $g$, stock-flow adjustments, and debt service-to-revenue using the empirical framework developed by Gourinchas and Obstfeld (2012). Consider a variable of interest $y_{i t}$, where subscript $i$ refers to the country and subscript $t$ to the period. We then estimate the conditional expectation of $y_{i t}$ as a function of the distance from the start of the fiscal crisis episode relative to a common baseline as follows:

$$
y_{i t}=\alpha_{i}+\sum_{k} \beta_{t+k} T_{i k}+\varepsilon_{i t}
$$

In equation (4), $T_{i k}$, is a dummy equal to 1 when the country $i$ is $k$ years away from the start of the fiscal crisis in year $t$, and 0 otherwise; $\alpha_{i}$ denotes country-fixed effects; and $\varepsilon_{i t}$ is the error term which captures all the remaining variation in the realization of our variable of interest. Given data constraints, we restrict our analysis to 7 -year windows ( 3 years before and 3 years after the event episode). Each parameter, $\beta_{t+k}$ captures the average change in $y$, at time $t+k$, relative to observations outside the 7-year window, which we interpret as "normal times". Figure 10 plots the $\beta_{t+k}$ parameter for each of the variables of interest.

Overall, our results suggest that primary balances in EMEs are above normal levels before a crisis but tend to deteriorate quickly, reaching a through when the crisis hits (Figure 10, panel A). By the time it bottoms out, the primary balance is about 1 percentage point of GDP below normal times. The rebound, however, is also swift with primary balances returning back to normal three years after the beginning of the crisis. In contrast, LIDCs show a pretty flat primary balance similar to the trends during normal times. In terms of the $r-g$, we do not find statistically significant differences around crisis episodes for both income groups (Figure 10, panel B). But the debt service-to-revenue in EMEs showed a significant upward trend, reaching a peak 41/4 percentage points above normal times two years after the start of the crisis (Figure 10, panel C). Taken together these findings point to the lagged response of the $r-g$ and its limited value as a leading indicator of problems yet to come (Moreno Badia et al. 2020; and Mauro and Zhou 2021). Finally, stock-flow adjustments show an upward trend in the run-up to the crisis in EMEs and at the onset in the case of LIDCs, though differences are negligible relative to tranquil times (Figure 10, panel D). 
Figure 10. Macroeconomic Dynamics during Crisis Episodes

A. Primary Balance

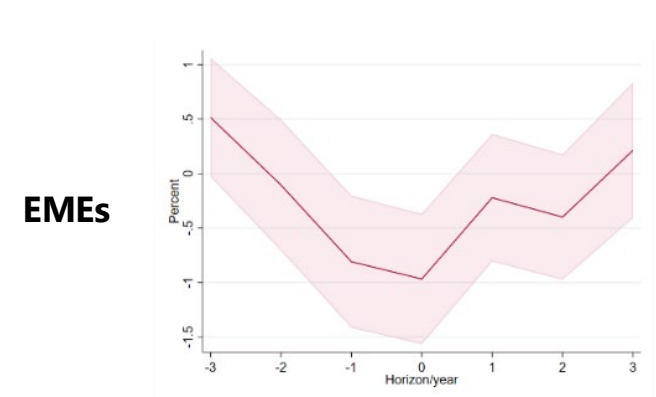

LIDCs

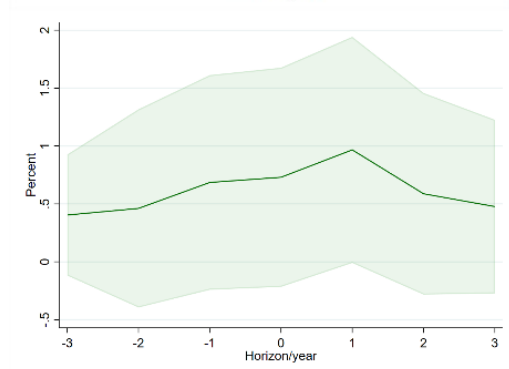

B. R-G
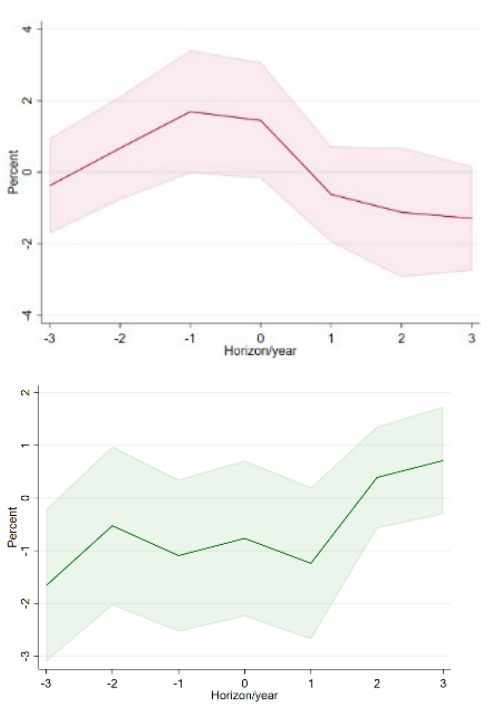

C. Debt Service to Revenue
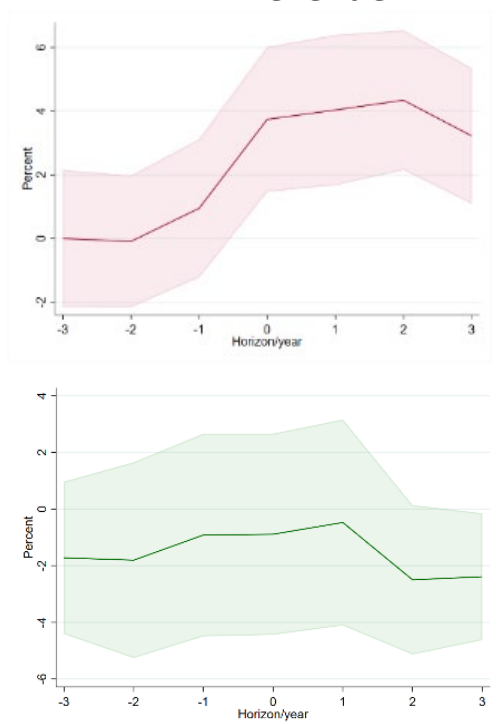

D. Stock Flow Adjustment
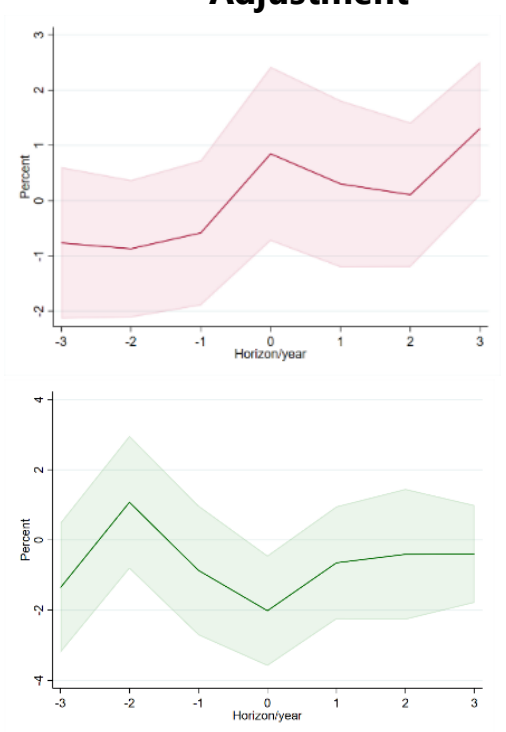

Source: Authors' calculations.

Note: These charts displayan event study based on the framework developed by Gourinchas and Obstfeld (2012) where $t=0$ is the start of the fiscal crisis. Each data point should be interpreted as the variable of interest at time $t+k$ relative to a "non-crisis benchmark". The shaded area denotes the 90 percent confidence interval for each conditional mean. 


\section{The Changing Dynamics over the Course of a Crisis}

The previous empirical findings emphasize that fiscal crises may not be preceded by significant changes in the $r-g$. But it does not necessarily follow that $r-g$ does not play a counterbalancing role, the overall impact of which may differ depending on which stage of the crisis the country is at and the length of the episode. To explore these questions more systematically, we try to disentangle the debt dynamics during the two phases-entry and exit—of a crisis. We first identify the peak as the point in time when debt reaches its maximum level after the onset of the crisis. The entry - what we refer to as into the crisis-is the period running three years before the start of the episode until its peak. The exit-what we call out of the crisis-is the period from the peak to the end of the episode.

Figure 11 plots the debt decomposition into and out of the crisis for each country group. Several features stand out. First, the primary deficits are a large driver behind debt accumulation in the entry phase, more so in EMEs where the cumulative effect is a staggering 19 percent of GDP. Second, the stock-flow adjustments are also very important, in this case more so for LIDCs where the cumulative impact is close to $181 / 2$ percent of GDP. Notably, the $r-g$ effect is also very large, though only in LIDCs is enough to offset the negative effects of other factors on debt dynamics. In EMEs, $r-g$ cannot prevent a sizable increase in debt in the entry phase. On the other hand, all components are significantly smaller for both country groups in the exit phase. To a certain extent, there is some normalization of interest rates in the recovery phase. But what makes a difference getting out of the crisis is the reversal of the primary deficits (which turn into surpluses) and the reduction of the stock-flow adjustments.

The trends described above refer to the average crisis episode. We next examine whether there are differences between the long haulers-countries for which the crisis duration is above the average for their respective income group-and short haulers. Figure 12 display the debt decomposition for each of them. As expected, debt accumulation in the entry phase is much larger in long haulers than short haulers irrespective of the income group. Also, the negative impact of primary deficits and stock-flow adjustments in the entry phase is sizable for long haulers though their relative importance varies-primary deficits being more important in EMEs and stock-flow adjustments in LIDCs. In the exit phase, the adverse debt dynamics are significantly downsized but while long-haulers run primary surpluses in EMEs, we still see primary deficits in LIDCs albeit of much smaller scale. What is common among both groups is the significant reduction in stock-flow adjustments. At the other end, short haulers display much more benign debt dynamics in the entry phase, but unlike long haulers stock-flow adjustments are the overriding force in both country groups. 


\section{Figure 11. Debt Decomposition in EMDEs around Fiscal Crisis Episodes}

(Cumulative, percent of GDP)

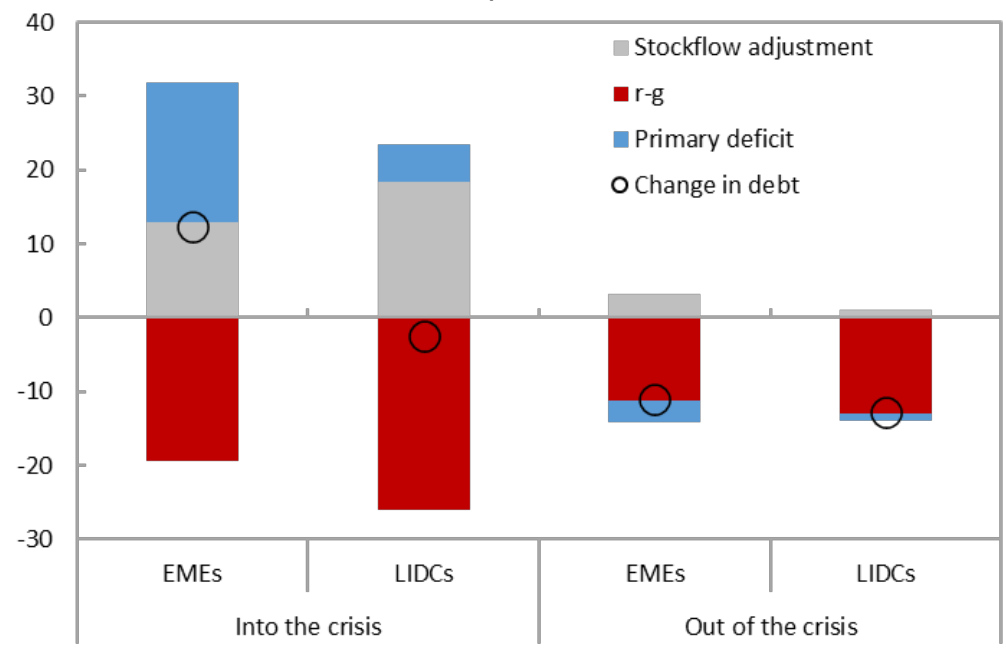

Sources: Moreno Badia et al. (2020); and authors' calculations.

Notes: Reported numbers are average cumulative changes. "Into the crisis" refer to the period three years before the start of the crisis to its peak. "Out of the crisis" is the period between the peak and the end of the crisis. Peak is the defined on the basis on debt levels.

Figure 12. Debt Dynamics around Fiscal Crisis by Duration (Cumulative, percent of GDP)

1. EMEs

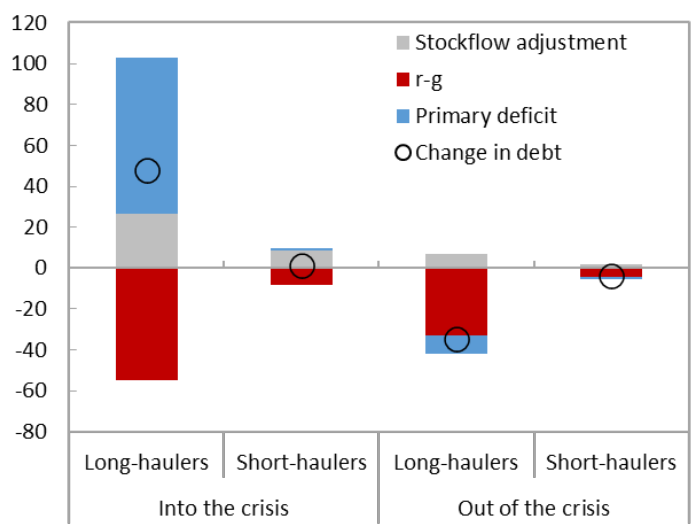

2. LIDCs

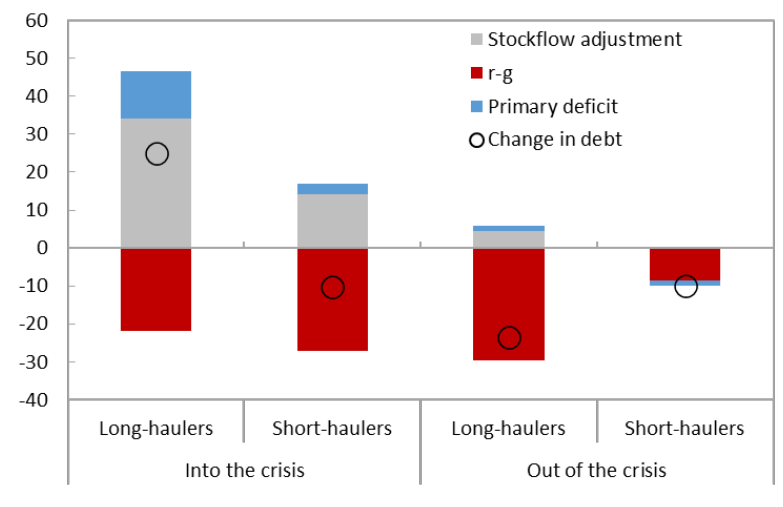

Sources: Moreno Badia et al. (2020); and authors' calculations.

Notes: "Into the crisis" refer to the period three years before the start of the crisis to its peak. "Out of the crisis" is the period between the peak and the end of the crisis. Peak is the defined based on debt levels. Longhaulers are those countries where the duration of the crisis is above the mean. Numbers reported are average cumulative changes.

The preceding results do not imply that the $r-g$ is immaterial. On balance, a striking regularity in all cases and phases of the crisis is that the $r$ - $g$ always plays a stabilizing role. Fundamentally, as illustrated by the event studies in the previous section, the $r-g$ remains negative for long stretches and only starts increasing at the onset of the crisis or thereafter. In the entry phase, it may not make a difference if the crisis is protracted. But on the exit, it does irrespective of the crisis type. Nonetheless, what we have shown is that one of most important hallmarks of fiscal 
crises in EMDEs, is that stock-flow adjustments are always a big part of the story in the way in. Given their importance, we examine what is behind them in the next section.

\section{DETERMINANTS OF STOCK-FLOW ADJUSTMENTS}

Stock-flow adjustments can arise for different reasons, including valuation effects through the impact of exchange depreciation on foreign currency denominated debt and below-the-line operations such as transactions in financial assets (for example, the injection of capital in banks), bailouts of state-owned enterprises, or government guarantees that have been called. Thus, to shed light on the drivers of stock-flow adjustments, we undertake the following decomposition:

$$
s f a_{t}=\varepsilon_{t}\left(1-\alpha_{t}\right)\left(1+i_{t}\right) d_{t-1}+b t l_{t}
$$

where $\varepsilon_{t}$ is the nominal exchange rate depreciation, $\alpha_{t}$ is the share of domestic-currency debt, and $b t l_{t}$ is a residual capturing below the line operations and errors and omissions. The first term is the so-called "valuation" effect, while the second mainly records the materialization of contingent liabilities. ${ }^{14}$ Figure 13 shows the relative importance of these two factors during the different phases of a fiscal crisis. ${ }^{15}$ Generally, valuation effects are sizable in the entry phase of the crisis accounting for about 8 and 103/4 percent of GDP of the debt increase in EMEs and LIDCs respectively. Below the line operations are even larger in the case of EMEs but also nonnegligible in LIDCs. In the way out of the crisis, valuation effects are still very much present while below the line operations do not play much of a role.

As discussed in section II, the paucity of quantitative information on the materialization of contingent liabilities makes it difficult to explore the factors behind below the line operations. However, we can get further insights, even if just indicative, by looking at close correlates of contingent liabilities. We focus on three-private debt, private external guaranteed debt, and other public sector external debt-and estimate a fixed-effect panel regression on the determinants of stock-flow adjustments. Following Jaramillo, Mulas-Granados, and Kimani (2017), we also control for the pre-existing level of debt, inflation, currency depreciation, and the share of external debt. For LIDCs, we also include a dummy for the years between decision and completion points to capture the debt relief associated with the HIPC initiative, which could have a negative impact on the stock-flow adjustments as a result of the debt reduction operations.

\footnotetext{
14 The stock-flow adjustments may also capture statistical errors, but data constraints do not allow us to quantify the importance of this term.

${ }^{15}$ Because of data constraints on external debt, the sample is restricted to 196 crisis episodes.
} 


\section{Figure 13. Debt Decomposition in EMEs around Fiscal Crisis Episodes}

(Cumulative, percent of GDP)

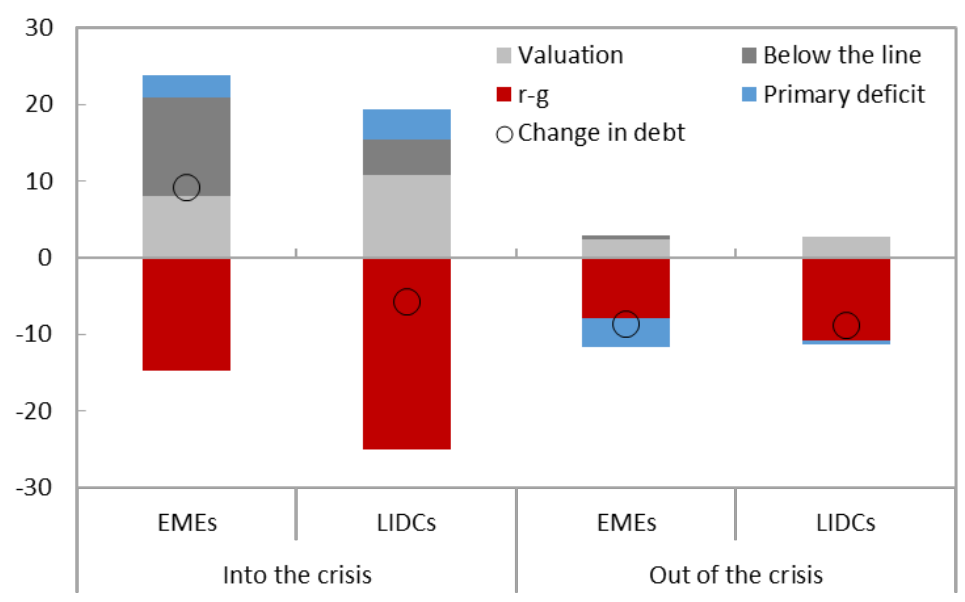

Sources: Moreno Badia et al. (2020); and authors' calculations.

Notes: Reported numbers are average cumulative changes. "Into the crisis" refer to the period three years before the start of the crisis to its peak. "Out of the crisis" is the period between the peak and the end of the crisis. Peak is the defined on the basis on debt levels.

Table 5 reports the estimates for EMEs and LIDCs. The first two columns look at the determinants of the stock-flow adjustment without making any distinction on whether a country is in a fiscal crisis. For both country groups we find that inflation and exchange rate depreciation are positively associated with the stock-flow adjustment. As expected, the impact of exchange rate depreciation increases with the share of external debt. Private debt, however, has a statistically significant positive effect only in EMEs. The next two columns show the interaction effects with fiscal crises. The valuation coefficient becomes larger when fiscal crises are factored in. However, private debt has a negative effect. A possible explanation is that our measure of stock-flow adjustments only captures annual changes and in the midst of a crisis private debt may migrate into the public sector balance sheet with a long lag. We next look at the two other measures of contingent liabilities. Overall, we find that the changes in private guaranteed external debt are positively associated with stock-flow adjustments but when in fiscal crisis it only matters for EMEs. On the other hand, other public sector external debt does not have a significant impact regardless.

To summarize, we find that the results on valuation effects are remarkably robust for both country groups. The higher the foreign exchange exposures, the larger the impact on the stockflow adjustments in the face of exchange rate depreciation. Below the line operations, on the other hand, are particularly important for EMEs and appear to be associated with contingent liabilities coming from the private sector.

\section{CONCLUSIONS}

Fighting COVID-19 has often been compared to fighting a war. And, as with other wars, it will likely leave behind a legacy of high debt in EMDEs that will need to be tackled. There is no question that a favorable $r-g$ would make that task immeasurably easier. But if the last year has taught us anything is the folly of prognosticating the future. Still, even if we were to assume the 
best of times, would it matter or is the $r-g$ just a red herring? In this paper we contribute to this debate by examining the debt dynamics in EMDEs over the last fifty years.

By using a more comprehensive dataset than previous studies, we are able to disentangle the differences between EMEs and LIDCs. Overall, we find that both income groups have benefitted from highly negative $r-g$, but there are no assurances going forward. Not only has the $r-g$ displayed an upward trend over the last several decades-more so in EMEs - but also its volatility is high and persistence low. More importantly, even with a low $r-g$, EMDEs have been racking up debt in recent years, suggesting that there is a limit as to how much a favorable $r-g$ can accomplish in the face of large primary deficits or stock-flow adjustments. Fiscal crisis episodes are instructive in that respect. The $r-g$ always plays a debt stabilizing role whether getting into the crisis or out of it. The big difference comes from primary deficits and stock-flow adjustments and only when those are corrected, does the debt return to a sustainable path.

The foregoing results do not suggest that the $r-g$ is immaterial, but they provide two important reminders at the current juncture. First, to the extent that foreign currency exposures are large, inflation and exchange rate stability are paramount. Second, more attention should be given to hidden debts as the materialization of contingent liabilities is often what gets EMDEs into trouble. 


\section{REFERENCES}

Abbas, S. A.Nazim Belhocine, A. ElGanainy, and M. Horton. 2011. "A Historical Public Debt Database," IMF Economic Review, Vol. 59, issue 4: 717-42, International Monetary Fund, Washington, DC.

Acosta-Ormaechea, S. 2020. "Public Debt Dynamics and Intra-Year Exchange Rate Fluctuations," IMF Working Paper No. 20/261, International Monetary Fund, Washington, DC.

Alexopoulou, I., I. Bunda and A. Ferrando. 2010. "Determinants of Government Bond Spreads in New EU Countries," Eastern European Economics. 48(5): 5-37.

Alves, M., S. De Clerck, and J. Gamboa-Arbelaez. 2020. "Public Sector Balance Sheet Database: Overview and Guide for Compilers and Users," IMF Working Paper No. 20/130, International Monetary Fund, Washington, DC.

Baldacci, E. and M. S. Kumar. 2010. "Fiscal Deficits, Public Debt, and Sovereign Bond Yields", IMF Working Paper. WP/10/184. International Monetary Fund, Washington DC.

Barrett, P. 2018. "Interest-Growth Differentials and Debt Limits in Advanced Economies," IMF Working Paper 18/82, International Monetary Fund, Washington DC.

Barro, R. 2020. "R Minus G," NBER Working Paper 28002, National Bureau of Economic Research, Cambridge, MA.

Blanchard, O. J. 2019. "Public Debt and Low Interest Rates," American Economic Review 109(4): 1197-1229.

Blanchard, O.J., J. Felman, and A. Subramanian. 2021. "Does the New Fiscal Consensus in Advanced Economies Travel to Emerging Markets? "Policy Brief 21-7, Peterson Institute for International Economics, Washington, DC.

Bohn, H. 1998. "The Behavior of US Public Debt and Deficits," Quarterly Journal Economics, Vol. 113(3), pp. 949-963.

Bova, E., M. Ruiz-Arranz, F. Toscani, and E. Ture (2019) "The Impact of Contingent Liability Realizations on Public Finances," International Tax and Public Finance, 26: 381-417.

Burger, J. D. B., F. Warnock, V. Cacdac Warnock .2018. "Currency Matters: Analyzing International Bond Portfolios," Journal of International Economics, 114: 376-388.

Buysse, K, F. De Sloover, and D. Essers. 2021. "Indebtedness around the World: Is the Sky the Limit?" National Bank of Belgium Economic Review, June 2021.

Campos, C., D. Jaimovich, and U. Panizza. 2006. "The Unexplained Part of Public Debt," Emerging Markets Review, 7(3): 228-243. 
Chinn, M. D. and H. Ito. 2006. "What Matters for Financial Development? Capital Controls, Institutions, and Interactions," Journal of Development Economics, Vol. 81, Issue 1:163192 (October).

Ciarlone, A., P. Piselli and G. Trebeschi. 2009. "Emerging Markets Spreads and Global Financial Conditions," Journal of International Financial Markets, Institutions and Money, Vol. 19, issue 2: 222-239.

Csontó, B. 2014. "Emerging Market Sovereign Bond Spreads and Shifts in Global Market Sentiment," Emerging Market Review, Vol. 20: 58-74.

Csontó, B. and I.V. Ivaschenko. 2013. "Determinants of Sovereign Bond Spreads in Emerging Markets: Local Fundamentals and Global Factors vs. Ever-Changing Misalignments," IMF Working Paper No. 13/164, International Monetary Fund, Washington, DC.

Dell'Erba, S., R. Hausmann and U. Panizza. 2013. "Debt Levels, Debt Composition, and Sovereign Spreads in Emerging and Advanced Economies," Oxford Review of Economic Policy, Vol. 29, iss. 3: $518-547$.

Di Serio, M., M. Fragetta, and G. Melina. 2021. "The Impact of $r-g$ on the Euro-Area Government Spending Multiplier," IMF Working Paper No. 21/39, International Monetary Fund, Washington, DC.

Escolano, J. 2010. "A Practical Guide to Public Debt Dynamics, Fiscal Sustainability, and Cyclical Adjustment of Budgetary Aggregates," IMF Technical Notes and Manuals 2010/02, International Monetary Fund, Washington DC.

Escolano, J., A. Shabunina, and J. Woo. 2017. "The Puzzle of Persistently Negative Interest-RateGrowth-Differentials: Financial Repression or Income Catch-Up?" Fiscal Studies, 38(2): 179217.

Evans, R. W. 2020. "Public Debt, Interest rates, and Negative Shocks," AEA Papers and Proceedings, 110: $137-140$.

Ghosh, A.R., J.I. Kim, E.G. Mendoza, J.D. Ostry and M.S. Qureshi. 2013. "Fiscal Fatigue, Fiscal Space and Debt Sustainability in Advanced Economies," The Economic Journal, 123: F4-F30.

Gourinchas, P.O. and M. Obstfeld. 2012. "Stories of the Twentieth Century for the Twenty-First." American Economic Journal: Macroeconomics, 4 (1): 226-65.

Graf von Luckner, C., J. Meyer, C. Reinhart, and C. Trebesch. 2021. "External Debt Restructurings: Delay and Replay," VoxEu (March 30) available at External sovereign debt restructurings: Delay and replay |VOX, CEPR Policy Portal (voxeu.org) 
Grömping, U. 2007. "Estimators of Relative Importance in Linear Regression Based on Variance Decomposition," The American Statistician, 61(2): 139-147.

Hartelius, K., K. Kashiwase and L.E. Kodres. 2008. "Emerging Market Spread Compression: Is it Real or is it Liquidity?" IMF Working Paper No. 08/10, International Monetary Fund, Washington, DC.

Hasanhodzic, J. 2020. "Simulating the Blanchard Conjecture in a Multiperiod Life Cycle Model," AEA Papers and Proceedings, 110: 137-140.

International Monetary Fund (IMF). 2016. "Analyzing and Managing Fiscal Risks. Best Practices." Fiscal Monitor (October), Washington, DC.

—_ 2019. "Heavily Indebted Poor Countries (HIPC) Initiative and Multilateral Debt Relief Initiative (MDRI)—Statistical Update," Washington, DC.

_ 2020. "State-Owned Enterprises: The Other Government." Fiscal Monitor (April) Chapter 3, Washington, DC.

_. 2021a. "A Fair Shot." Fiscal Monitor (April), Washington, DC.

—_. 2021b. "Review of the Debt Sustainability Framework for Market Access Countries," Washington, DC.

Jaramillo, L., C. Mulas-Granados, and E. Kimani. 2017. "Debt Spikes and Stock Flow Adjustments: Emerging Economies in Perspective," Journal of Economics and Business, Vol. 94: 1-14.

Jaramillo, L., and A. Weber. 2013. "Bond Yields in Emerging Economies: It Matters What State You are in," Emerging Markets Review, Vol. 17: 169-85.

Jordà, O., M. Schularick, and A.M. Taylor. 2016. "Sovereigns Versus Banks: Credit, Crises, and Consequences." Journal of the European Economic Association 14 (1): 45-79.

Kumar, M.S. and E.Baldacci. 2010. "Fiscal Deficits, Public Debt, and Sovereign Bond Yields," IMF Working Paper No. 10/184, International Monetary Fund, Washington, DC.

Lian, W., A.F. Presbitero, and U. Wiriadinat. 2020. "Public Debt and r - g at Risk," IMF Working Paper No. 20/137, International Monetary Fund, Washington, DC.

Mauro, P., and J. Zhou. 2021. "r-g<0: Can We Sleep More Soundly?" IMF Economic Review 69: 197229.

Mauro, P, R. Romeu, A. Binder and A. Zaman. 2015. "A Modern History of Fiscal Prudence and Profligacy," Journal of Monetary Economics, 76: 55-70.

CInternational Monetary Fund. Not for Redistribution 
Mbaye, S., M. Moreno-Badia, and K. Chae. 2018a. "Bailing Out the People: When Private Debt Becomes Public." IMF Working Paper No. 18/141, International Monetary Fund, Washington, DC.

—_ 2018b. "The Global Debt Database: Methodology and Sources." IMF Working Paper No. 18/111, International Monetary Fund, Washington, DC.

Medas, P., T. Poghosyan, Y. Xu, J. Farah-Yacoub, and K. Gerling. 2018. "Fiscal Crises," Journal of International Money and Finance, Vol. 88: 191-207.

Mehrotra, N. R., and D. Sergeyev. 2020. "Debt Sustainability in a Low Interest Rate World," CEPR Discussion Paper No. DP15282.

Miyayima, K., M.S. Mohanty, and T. Chan. 2015. "Emerging Market Local Currency Bonds: Diversification and Stability," Emerging Market Review, Vol. 22: 126-135.

Moreno-Badia, M., P. Medas, P. Gupta, and Y. Xiang. 2020. "Debt is Not Free." IMF Working Paper No. 20/1, International Monetary Fund, Washington, DC.

Panizza, U., and F. Taddei. 2020. "Local Currency Denominated Sovereign Loans: A Portfolio Approach to Tackle Moral Hazard and Provide Insurance," Working Paper No. HEIDWP092020, Graduate Institute of International and Development Studies, Geneva.

Turner, D. and F. Spinelli. 2011. "Explaining the Interest-Rate-Growth Differential Underlying Government Debt Dynamics," OECD Economics Department Working Papers 919, OECD Publishing.

Reinhart, C., and K. Rogoff. 2009. "The Aftermath of Financial Crises," American Economic Review, Vol. 99: 466-72.

—. 2011. "From Financial Crash to Debt Crisis," American Economic Review, Vol. 101: 16761706.

_. 2013. "Banking Crises: An Equal Opportunity Menace," Journal of Banking and Finance vol. 37, vol. 11: 4557-73.

Reinhart, C., K. Rogoff, and M. Savastano. 2003. "Debt Intolerance," Brookings Papers for Economic Activity Vol. 1, Spring: 1-74.

Sabbadini, R. 2018. "Overcoming the Original Sin: Gains from Local Currency External Debt," Banco Central do Brasil Working Paper No. 484, Banco Central do Brasil, Brasilia. 


\section{TABLES}

Table 1. Correlation between Real Interest Rate, Real Growth, and Real R-G

\begin{tabular}{|c|c|c|c|c|}
\hline & \multicolumn{2}{|c|}{ EMEs } & \multicolumn{2}{|c|}{ LIDCs } \\
\hline & $\begin{array}{c}\text { Pooling } \\
\text { (1) }\end{array}$ & $\begin{array}{c}\text { Average } \\
\text { Correlation } \\
(2)\end{array}$ & $\begin{array}{c}\text { Pooling } \\
\text { (3) }\end{array}$ & $\begin{array}{c}\text { Average } \\
\text { Correlation } \\
(4)\end{array}$ \\
\hline \multicolumn{5}{|c|}{$\begin{array}{l}\text { Full } \\
\text { Sample }\end{array}$} \\
\hline$r-g, g$ & -0.27 & -0.41 & -0.32 & -0.38 \\
\hline$r-g, r$ & 0.92 & 0.85 & 0.89 & 0.83 \\
\hline$r, g$ & 0.09 & 0.02 & 0.14 & 0.11 \\
\hline $\mathrm{N}$ & 3041 & 3041 & 1782 & 1782 \\
\hline \multicolumn{5}{|c|}{ Pre GFC } \\
\hline$r-g, g$ & -0.21 & -0.38 & -0.32 & -0.33 \\
\hline$r-g, r$ & 0.94 & 0.85 & 0.90 & 0.83 \\
\hline$r, g$ & 0.11 & 0.04 & 0.11 & 0.13 \\
\hline $\mathrm{N}$ & 2145 & 2145 & 1209 & 1209 \\
\hline \multicolumn{5}{|l|}{$\begin{array}{l}\text { Post } \\
\text { GFC }\end{array}$} \\
\hline$r-g, g$ & -0.54 & -0.56 & -0.36 & -0.45 \\
\hline$r-g, r$ & 0.71 & 0.79 & 0.83 & 0.80 \\
\hline$r, g$ & 0.05 & -0.07 & 0.20 & 0.04 \\
\hline $\mathrm{N}$ & 896 & 896 & 573 & 573 \\
\hline
\end{tabular}

Source: Authors' calculations.

Notes: $r-g$ is defined in nominal terms (see equation 1 in the main text). $r$ is the real interest rate and $g$ the real growth rates. Real variables are calculated using the GDP deflator. The second and fourth columns report the average of the within-country correlation. 
Table 2. Determinants of the Interest-Growth Differential

\begin{tabular}{|c|c|c|c|c|c|c|}
\hline & (1) & (2) & (3) & (4) & (5) & (6) \\
\hline VARIABLES & EMEs & LIDCs & EMEs & LIDCs & EMEs & LIDCs \\
\hline \multirow[t]{2}{*}{$\begin{array}{l}\text { Lagged Real Effective Interest } \\
\text { Rate }\end{array}$} & $0.241^{\star * *}$ & $0.167^{* * *}$ & $0.215^{\star * *}$ & $0.165^{\star * *}$ & $0.354^{* * *}$ & $0.166^{* * *}$ \\
\hline & $(0.062)$ & $(0.049)$ & $(0.059)$ & $(0.049)$ & $(0.093)$ & $(0.049)$ \\
\hline \multirow[t]{2}{*}{ Lagged Real GDP Growth } & $-0.179^{* * *}$ & 0.037 & $-0.141^{\star *}$ & 0.037 & $-0.243^{* * *}$ & 0.037 \\
\hline & $(0.055)$ & $(0.068)$ & $(0.061)$ & $(0.068)$ & $(0.077)$ & $(0.068)$ \\
\hline \multirow[t]{2}{*}{ Financial Openness Index } & $5.404^{* * *}$ & 0.813 & $5.253^{* * *}$ & 0.827 & $4.169^{\star * *}$ & 0.819 \\
\hline & $(1.270)$ & $(2.347)$ & $(1.351)$ & (2.364) & $(1.531)$ & (2.359) \\
\hline \multirow[t]{2}{*}{ Lagged Inflation } & -0.005 & -0.023 & -0.006 & -0.024 & 0.014 & -0.023 \\
\hline & $(0.020)$ & $(0.032)$ & $(0.018)$ & $(0.032)$ & $(0.025)$ & $(0.032)$ \\
\hline \multirow[t]{2}{*}{ Lagged Public Debt } & 0.008 & $-0.027^{\star *}$ & 0.009 & $-0.027^{* *}$ & 0.008 & $-0.027^{\star *}$ \\
\hline & $(0.013)$ & $(0.013)$ & $(0.012)$ & $(0.013)$ & $(0.013)$ & $(0.013)$ \\
\hline \multirow[t]{2}{*}{ Change in Public Debt } & $0.178^{* * *}$ & $0.107^{* * *}$ & $0.174^{\star * *}$ & $0.107^{\star * *}$ & $0.128^{*}$ & $0.107^{* * *}$ \\
\hline & $(0.062)$ & $(0.024)$ & $(0.063)$ & $(0.024)$ & $(0.071)$ & $(0.024)$ \\
\hline \multirow[t]{2}{*}{ Lagged VIX } & $0.194^{* * *}$ & $0.089^{* * *}$ & $0.202^{* * *}$ & $0.089^{* * *}$ & $0.123^{* * *}$ & $0.089^{* * *}$ \\
\hline & $(0.023)$ & $(0.021)$ & $(0.025)$ & $(0.021)$ & $(0.023)$ & $(0.021)$ \\
\hline \multirow[t]{2}{*}{ Oil Price } & -0.016 & -0.023 & -0.031 & -0.025 & -0.001 & -0.023 \\
\hline & $(0.020)$ & $(0.018)$ & $(0.022)$ & $(0.018)$ & $(0.020)$ & $(0.018)$ \\
\hline \multirow[t]{2}{*}{ Non-Fuel Commodity Price } & 0.013 & 0.002 & 0.017 & 0.002 & -0.006 & 0.002 \\
\hline & $(0.016)$ & $(0.018)$ & $(0.018)$ & $(0.018)$ & $(0.017)$ & $(0.018)$ \\
\hline \multirow[t]{2}{*}{ HIPC } & & -0.119 & & -0.013 & & -0.101 \\
\hline & & $(0.556)$ & & $(0.562)$ & & $(0.613)$ \\
\hline \multirow{2}{*}{$\begin{array}{l}\text { Lagged Exchange Rate } \\
\text { Depreciation }\end{array}$} & $-0.074^{* * *}$ & $-0.057^{* * *}$ & $-0.075^{\star * *}$ & $-0.057^{* * *}$ & $-0.069^{* * *}$ & $-0.057^{* * *}$ \\
\hline & $(0.009)$ & $(0.013)$ & $(0.009)$ & $(0.014)$ & $(0.012)$ & $(0.013)$ \\
\hline \multirow[t]{2}{*}{ Lagged Private Debt } & 0.012 & 0.021 & 0.019 & 0.013 & $0.035^{*}$ & 0.020 \\
\hline & $(0.013)$ & $(0.042)$ & $(0.014)$ & $(0.041)$ & $(0.018)$ & $(0.042)$ \\
\hline \multirow[t]{2}{*}{ Share Official Debt } & & & $-0.064^{\star *}$ & -0.013 & & \\
\hline & & & $(0.025)$ & $(0.019)$ & & \\
\hline \multirow[t]{2}{*}{ Share Concessional Debt } & & & & & $-0.088^{*}$ & -0.002 \\
\hline & & & & & $(0.049)$ & $(0.020)$ \\
\hline \multirow[t]{2}{*}{ Constant } & $-11.881^{* * *}$ & $-6.546^{* * *}$ & $-10.490^{* * *}$ & $-5.532^{* *}$ & $-8.172^{* * *}$ & $-6.476^{\star \star *}$ \\
\hline & $(1.542)$ & $(1.841)$ & $(2.028)$ & $(2.218)$ & $(1.557)$ & $(2.071)$ \\
\hline Observations & 1,670 & 1,304 & 1,581 & 1,304 & 1,050 & 1,304 \\
\hline R-squared & 0.382 & 0.259 & 0.395 & 0.260 & 0.468 & 0.259 \\
\hline Number of countries & 66 & 52 & 64 & 52 & 43 & 52 \\
\hline \multicolumn{7}{|l|}{ General dominance statistics: } \\
\hline $\begin{array}{l}\text { Lag Real Effective } \\
\text { Interest Rate }\end{array}$ & 0.215 & 0.185 & 0.258 & 0.175 & 0.269 & 0.175 \\
\hline Lag Real GDP Growth & 0.013 & 0.002 & 0.007 & 0.002 & 0.011 & 0.001 \\
\hline
\end{tabular}

Source: Authors' calculations. Notes: Fixed effects panel regressions. Robust standard errors are in parentheses and are clustered at country level. ${ }^{* *} p<0.01,{ }^{* *} p<0.05,{ }^{*} p<0.1$ represent the significance level, respectively. Given large outliers, $r-g$, inflation, and public debt are winsorized to the top and bottom 1 percent. General dominance statistics are derived as a weighted average marginal/incremental contribution to the overall fit statistic an independent variable makes across all models in which the independent variable is included. The coefficient represents the general dominance statistic vector standardized to be out of 100 percent.

\section{CInternational Monetary Fund. Not for Redistribution}


Table 3. Decomposition of Debt Changes

\begin{tabular}{lcccccc}
\multicolumn{7}{c}{ (Percent of GDP) } \\
\hline & $\begin{array}{c}\text { Change } \\
\text { in Debt }\end{array}$ & $\begin{array}{c}\text { Primary } \\
\text { Deficit }\end{array}$ & $r-g$ & $r$ & $g$ & SFA \\
\hline Full Sample (1970-2018) & -0.21 & 0.69 & -3.74 & 1.99 & -5.73 & 2.85 \\
& & & & & & \\
EMEs & 0.15 & 0.41 & -2.68 & 2.35 & -5.03 & 2.42 \\
LIDCs & -0.83 & 1.18 & -5.61 & 1.36 & -6.97 & 3.60 \\
& & & & & & \\
EMEs & 1.60 & 2.29 & -6.67 & 2.63 & -9.30 & 5.98 \\
1980s & -0.07 & 1.77 & -3.66 & 2.84 & -6.50 & 1.82 \\
1990s & -1.30 & -1.36 & -2.22 & 2.46 & -4.68 & 2.29 \\
2000s & 1.20 & 0.62 & -1.13 & 1.99 & -3.12 & 1.72 \\
2010s & & & & & & \\
& & & & & & \\
LIDCs & 3.14 & 1.24 & -3.89 & 1.63 & -5.52 & 5.79 \\
1980s & 0.01 & 0.74 & -6.93 & 1.87 & -8.81 & 6.21 \\
1990s & -4.92 & 0.51 & -7.74 & 1.34 & -9.08 & 2.32 \\
2000s & 1.39 & 2.01 & -3.36 & 1.05 & -4.41 & 2.74 \\
\hline 2010s & & & & & &
\end{tabular}

Source: Authors' calculations.

Notes: Reported numbers are the average annual changes of debt and contributions. A positive number means that component is contributing to an increase in debt. The term $r$ refers $\frac{i_{t}}{1+\gamma_{t}} d_{t-1}$, while the term $\mathrm{g}$ refers to $-\frac{\gamma_{t}}{1+\gamma_{t}} d_{t-1}$, and SFA refers to the stock-flow adjustment. 
Table 4. Fiscal Crises in EMDEs, 1970-2018

\begin{tabular}{lcc}
\hline & EMEs & LIDCs \\
\hline $\begin{array}{l}\text { Number of crisis starts } \\
\text { of which (percent) }\end{array}$ & 220 & 214 \\
$\quad$ Credit event & 59.6 & 82.0 \\
$\quad$ Exceptionally large official financing & 21.1 & 18.0 \\
$\quad$ Implicit domestic default & 9.4 & 4.7 \\
$\quad$ Loss of market confidence & 21.5 & 2.8 \\
& & \\
Average per country & 2.4 & 3.7 \\
Average duration & 5.3 & 6.1 \\
& & \\
Persistence (percent of crises) & 17.7 & 29.4 \\
Long haulers (percent of crises) & 33.6 & 35.5 \\
\hline
\end{tabular}

Sources: Moreno Badia et al (2020); and authors' calculations.

Notes: Crisis starts can be associated with more than one criterion. A year is considered to be a fiscal crisis year when at least one of the four criteria (credit event, exceptionally large official financing, implicit domestic default, loss of market confidence) is met. To separate between crisis events, we require at least two years of no fiscal crisis between the distinct events. 
Table 5. Determinants of Stock-Flow Adjustment

\begin{tabular}{|c|c|c|c|c|c|c|c|c|}
\hline VARIABLES & $\begin{array}{c}(1) \\
\text { EMEs }\end{array}$ & $\begin{array}{c}(2) \\
\text { LIDCs }\end{array}$ & $\begin{array}{c}(3) \\
\text { EMEs }\end{array}$ & $\begin{array}{c}(4) \\
\text { LIDCs }\end{array}$ & $\begin{array}{c}(5) \\
\text { EMEs }\end{array}$ & $\begin{array}{c}(6) \\
\text { LIDCs } \\
\end{array}$ & $\begin{array}{c}(7) \\
\text { EMES }\end{array}$ & $\begin{array}{c}(8) \\
\text { LIDCs }\end{array}$ \\
\hline Lag public debt & $\begin{array}{c}-0.037^{* *} \\
(0.019)\end{array}$ & $\begin{array}{l}0.036 * * \\
(0.013)\end{array}$ & $\begin{array}{l}-0.025 \\
(0.021)\end{array}$ & $\begin{array}{c}0.041^{* * *} \\
(0.014)\end{array}$ & $\begin{array}{c}0.023 \\
(0.032)\end{array}$ & $\begin{array}{c}0.044 \\
(0.055)\end{array}$ & $\begin{array}{c}0.052^{*} \\
(0.029)\end{array}$ & $\begin{array}{c}0.038 \\
(0.063)\end{array}$ \\
\hline Inflation & $\begin{array}{c}0.065^{* * *} \\
(0.010)\end{array}$ & $\begin{array}{c}0.025 \\
(0.065)\end{array}$ & $\begin{array}{c}0.104^{* * *} \\
(0.013)\end{array}$ & $\begin{array}{c}0.129^{\star * *} \\
(0.029)\end{array}$ & $\begin{array}{c}0.094^{* * *} \\
(0.018)\end{array}$ & $\begin{array}{c}-0.012 \\
(0.037)\end{array}$ & $\begin{array}{l}0.114^{\star * *} \\
(0.017)\end{array}$ & $\begin{array}{c}0.054 \\
(0.054)\end{array}$ \\
\hline Lag External public debt * depreciation & $\begin{array}{c}0.004^{* * *} \\
(0.001)\end{array}$ & $\begin{array}{c}0.001^{*} \\
(0.001)\end{array}$ & & & $\begin{array}{c}0.001 \\
(0.001)\end{array}$ & $\begin{array}{c}0.001 \\
(0.001)\end{array}$ & & \\
\hline Fiscal crisis starts & $\begin{array}{c}0.331 \\
(0.929)\end{array}$ & $\begin{array}{c}-1.776^{\star *} \\
(0.759)\end{array}$ & & & & & & \\
\hline Lag private debt & $\begin{array}{l}0.017^{* *} \\
(0.008)\end{array}$ & $\begin{array}{l}-0.020 \\
(0.034)\end{array}$ & $\begin{array}{c}0.010 \\
(0.009)\end{array}$ & $\begin{array}{c}-0.016 \\
(0.034)\end{array}$ & & & & \\
\hline HIPC & & $\begin{array}{l}-1.649 \\
(1.513)\end{array}$ & & $\begin{array}{c}-1.974 \\
(1.510)\end{array}$ & & $\begin{array}{c}-3.452 \\
(2.337)\end{array}$ & & $\begin{array}{c}-4.314^{\star *} \\
(2.019)\end{array}$ \\
\hline Lag private debt * fiscal crisis & & & $\begin{array}{c}-0.037^{* *} \\
(0.016)\end{array}$ & $\begin{array}{l}-0.090^{*} \\
(0.047)\end{array}$ & & & & \\
\hline Lag External public debt * depreciation * fiscal crisis & & & $\begin{array}{l}0.009^{* * *} \\
(0.002)\end{array}$ & $\begin{array}{l}0.002^{* * *} \\
(0.001)\end{array}$ & & & $\begin{array}{l}0.003^{* * *} \\
(0.001)\end{array}$ & $\begin{array}{l}0.002^{* * *} \\
(0.000)\end{array}$ \\
\hline $5 y$ change of other public sector debt & & & & & $\begin{array}{c}0.090 \\
(0.056)\end{array}$ & $\begin{array}{c}0.288 \\
(0.392)\end{array}$ & & \\
\hline $5 y$ change of private external guaranteed debt & & & & & $\begin{array}{l}1.352^{* \star *} \\
(0.311)\end{array}$ & $\begin{array}{c}2.178^{*} \\
(1.139)\end{array}$ & & \\
\hline $5 y$ change of private external guaranteed debt * & & & & & & & & \\
\hline fiscal crisis & & & & & & & $\begin{array}{c}1.229^{*} \\
(0.628)\end{array}$ & $\begin{array}{c}6.380 \\
(5.697)\end{array}$ \\
\hline $5 y$ change of other public sector debt * fiscal crisis & & & & & & & $\begin{array}{c}0.043 \\
(0.221)\end{array}$ & $\begin{array}{c}0.640 \\
(0.451)\end{array}$ \\
\hline Constant & $\begin{array}{l}2.014^{* *} \\
(0.894)\end{array}$ & $\begin{array}{c}1.425 \\
(1.107)\end{array}$ & $\begin{array}{l}1.863^{* *} \\
(0.805)\end{array}$ & $\begin{array}{c}0.536 \\
(1.070)\end{array}$ & $\begin{array}{c}0.830 \\
(1.347)\end{array}$ & $\begin{array}{c}4.004 \\
(3.615)\end{array}$ & $\begin{array}{c}-0.849 \\
(1.156)\end{array}$ & $\begin{array}{c}3.814 \\
(3.897)\end{array}$ \\
\hline Observations & 1,838 & 1,417 & 1,838 & 1,417 & 743 & 233 & 743 & 233 \\
\hline R-squared & 0.294 & 0.157 & 0.198 & 0.115 & 0.452 & 0.136 & 0.414 & 0.090 \\
\hline Number of countries & 67 & 54 & 67 & 54 & 42 & 21 & 42 & 21 \\
\hline
\end{tabular}

Source: Author's calculations.

Note: This table show s fixed effects panel regressions where the dependent variable is the stock flow adjustment. Robust standard errors are in parentheses and are clustered at country level. ${ }^{* *} p<0.01,{ }^{* *} p<0.05,{ }^{*} p<0.1$ represent the significance level, respectively. HIPC is a dummy variable equal to 1 if if the country w as in the period betw een HIPC decision and completion, and zero otherw ise. Stock flow adjustment, inflation, exchange rate 


\section{APPENDIX. DATA: DEFINITIONS AND SOURCES}

Our sample comprises an unbalanced panel of 150 countries-92 EMEs and 58 LIDCs, using the present-day IMF's World Economic Outlook classification (Table A.1.1)—over 1971-2018. We use these country groups, as customary, fully cognizant of the fact that some EMEs were considered LIDCs in earlier years of our sample.

Table A.1.1. Country Classification

Emerging markets

\begin{tabular}{|c|c|c|c|}
\hline \multicolumn{2}{|c|}{ Emerging markets } & \multicolumn{2}{|c|}{ Low-income Developing Countries } \\
\hline Albania & Lebanon & Afghanistan & Sudan \\
\hline Algeria & Libya & Bangladesh & São Tomé and Príncipe \\
\hline Angola & Macedonia, FYR & Benin & Tajikistan \\
\hline Antigua and Barbuda & Malaysia & Bhutan & Tanzania \\
\hline Argentina & Maldives & Burkina Faso & Timor-Leste \\
\hline Armenia & Marshall Islands & Burundi & Togo \\
\hline Azerbaijan & Mauritius & Cambodia & Uganda \\
\hline Bahamas, The & Mexico & Cameroon & Uzbekistan \\
\hline Bahrain & Micronesia & Central African Republic & Vietnam \\
\hline Barbados & Mongolia & Chad & Yemen \\
\hline Belarus & Montenegro & Comoros & Zambia \\
\hline Belize & Morocco & Congo, Democratic Republic of the & Zimbabwe \\
\hline Bolivia & Namibia & Congo, Republic of & \\
\hline Bosnia and Herzegovina & Oman & Côte d'Ivoire & \\
\hline Botswana & Pakistan & Djibouti & \\
\hline Brazil & Panama & Eritrea & \\
\hline Brunei Darussalam & Paraguay & Ethiopia & \\
\hline Bulgaria & Peru & Gambia, The & \\
\hline Cabo Verde & Philippines & Ghana & \\
\hline Chile & Poland & Guinea & \\
\hline China & Qatar & Guinea-Bissau & \\
\hline Colombia & Romania & Haiti & \\
\hline Costa Rica & Russia & Honduras & \\
\hline Croatia & Saudi Arabia & Kenya & \\
\hline Dominica & Serbia & Kiribati & \\
\hline Dominican Republic & Seychelles & Kyrgyz Republic & \\
\hline Ecuador & South Africa & Lao P.D.R. & \\
\hline Egypt & Sri Lanka & Lesotho & \\
\hline El Salvador & St. Kitts and Nevis & Liberia & \\
\hline Equatorial Guinea & St. Lucia & Madagascar & \\
\hline Fiji & St. Vincent and the Grenadines & Malawi & \\
\hline Gabon & Suriname & Mali & \\
\hline Georgia & Swaziland & Mauritania & \\
\hline Grenada & Syria & Moldova & \\
\hline Guatemala & Thailand & Mozambique & \\
\hline Guyana & Tonga & Myanmar & \\
\hline Hungary & Trinidad and Tobago & Nepal & \\
\hline India & Tunisia & Nicaragua & \\
\hline Indonesia & Turkey & Niger & \\
\hline Iran & Turkmenistan & Nigeria & \\
\hline Iraq & Tuvalu & Papua New Guinea & \\
\hline Jamaica & Ukraine & Rwanda & \\
\hline Jordan & United Arab Emirates & Senegal & \\
\hline Kazakhstan & Uruguay & Sierra Leone & \\
\hline Kosovo & Vanuatu & Solomon Islands & \\
\hline Kuwait & Venezuela & South Sudan & \\
\hline
\end{tabular}


Table A.1.2 gives the data sources and definitions. Building long time series for EMDEs is a challenging exercise as the various available sources cover different periods and the methodological approach is not always consistent across them. Our strategy is to maximize the time coverage while keeping a consistent definition at least at the country level. With that purpose in mind, original data series were adjusted for differences in definition and coverage whenever feasible. This means that our data span varies depending on the variables and countries. The biggest data constraint often comes from the series on interest expense, which has implications for the calculations on the $r-g$ and the primary balance. In particular, the coverage grows from 19 countries accounting for about 38 percent of EMDEs' output in 1971 to 99 percent of GDP by 2018, falling only 5 countries shy of accounting for the entire universe of EMDEs (Figure A.1.1).

Figure A.1.1. Country Coverage: Interest-Growth Differential

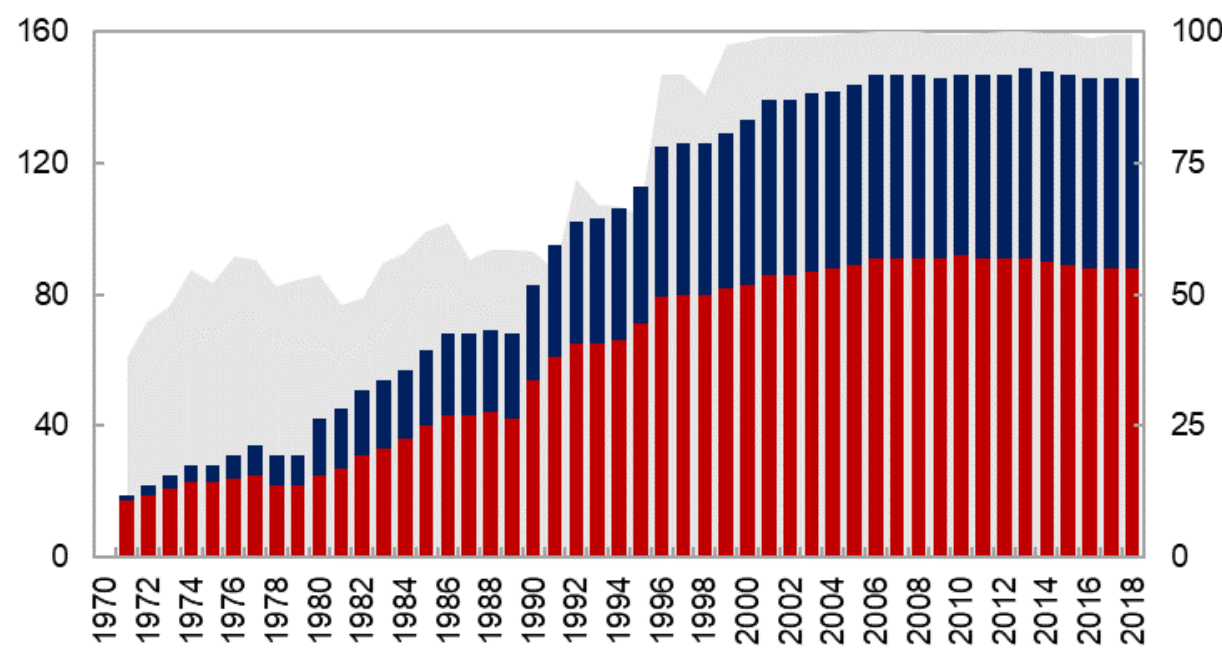

Share of GDP (RHS) - Number of EMEs number of LIDCs

Sources: IMF, World Economic Outlook; Mbaye, Moreno Badia, and Chae (2018b); and authors' calculations. Notes: For each date, the GDP share refers to the percentage of EMDE's output covered in our sample. 
Table A.1.2. Variables: Definitions and Sources

\begin{tabular}{|c|c|c|}
\hline Variable & Source & Notes \\
\hline \multicolumn{3}{|l|}{ Fiscal Variables } \\
\hline $\begin{array}{l}\text { Public debt in } \\
\text { percent ofGDP }\end{array}$ & $\begin{array}{l}\text { IMF, Global Debt Database } \\
\text { (Mbaye, Moreno Badia, and } \\
\text { Chae } 2018 \mathrm{~b} \text { ) }\end{array}$ & $\begin{array}{l}\text { Public debt includes total debt liabilities of the government with domestic and foreign creditors. } \\
\text { In compiling public debt series for each country, we look at the different perimeters of government (non-financial public sector, } \\
\text { general government, and central government) for which the Global Debt Database reports data, choosing the debt category for which } \\
\text { the time series is the longest. In many cases, particularly, among LIDCs, this results in a narrow definition of debt (central } \\
\text { government) but ensures the consistency of the series across time. In contrast, previous studies have often used a hybrid approach to } \\
\text { compile debt statistics, switching debt concepts depending on availability which may have yielded longer but inconsistent time series }\end{array}$ \\
\hline $\begin{array}{l}\text { General } \\
\text { government } \\
\text { interest expenses } \\
\text { in percent of GDP }\end{array}$ & $\begin{array}{l}\text { IMF, World Economic } \\
\text { Outlook; Medas et al (2018); } \\
\text { Abbas et al(2011) }\end{array}$ & \\
\hline $\begin{array}{l}\text { Public debt } \\
\text { service in percent } \\
\text { of revenue }\end{array}$ & $\begin{array}{l}\text { IMF, World Economic } \\
\text { Outlook; World Bank, World } \\
\text { Development Indicators. }\end{array}$ & Public debt service includes interest expense a nd external debt amortization. \\
\hline $\begin{array}{l}\text { General } \\
\text { government } \\
\text { primary balance, } \\
\text { percent of GDP }\end{array}$ & $\begin{array}{l}\text { IMF, World Economic } \\
\text { Outlook; Medas et al. (2018); } \\
\text { Abbas et al. (2011); Mauro et } \\
\text { al.(2015). }\end{array}$ & \\
\hline $\begin{array}{l}\text { Stock and flow } \\
\text { adjustment }\end{array}$ & $\begin{array}{l}\text { Authors' calculations based on } \\
\text { IMF, World Economic } \\
\text { Outlook }\end{array}$ & See equation (2) in main text. \\
\hline \multicolumn{3}{|c|}{ Macroeconomic Variables } \\
\hline $\begin{array}{l}\text { Interest-growth } \\
\text { differential }\end{array}$ & $\begin{array}{l}\text { Authors' calculations based on } \\
\text { IMF, World Economic } \\
\text { Outlook, and Global Debt } \\
\text { Database (Mbaye, Moreno } \\
\text { Badia, and Chae 2018b), } \\
\text { Abbas etal(2011) }\end{array}$ & $\begin{array}{l}\text { Calculated as } \frac{i_{t}-\gamma_{t}}{1+\gamma_{t}} \text { where } i_{t} \text { is the nominal effective interest ra te and } \gamma_{t} \text { is the nominal GDP growth rate. } \\
\text { The average effective interestra te on debt is computed a s thera tio of theinterest } \\
\text { bill in year } t \text { to the stock of government debt (average of debt stocks of year-end } t \\
\text { and } t-1 \text { ). }\end{array}$ \\
\hline Inflation & $\begin{array}{l}\text { IMF, World Economic } \\
\text { Outlook. }\end{array}$ & Percent change of Consumer Price Index, period average \\
\hline Deflator & $\begin{array}{l}\text { IMF, World Economic } \\
\text { Outlook. }\end{array}$ & Percent change of GDP deflator. \\
\hline \multicolumn{3}{|l|}{ External } \\
\hline $\begin{array}{l}\text { Exchange rate } \\
\text { depreciation }\end{array}$ & $\begin{array}{l}\text { IMF, World Economic } \\
\text { Outlook }\end{array}$ & Percent change of exchange rate (national current units per U.S. dollar, end of period) \\
\hline
\end{tabular}




\begin{tabular}{|c|c|c|}
\hline Variable & Source & Notes \\
\hline \multicolumn{3}{|l|}{ External (con't) } \\
\hline $\begin{array}{l}\text { External debt } \\
\text { stocks, other } \\
\text { public sector } \\
\text { (percent of GDP) }\end{array}$ & $\begin{array}{l}\text { Authors' calculations based on } \\
\text { IMF, World Economic } \\
\text { Outlook; and International } \\
\text { Debt Statistics (IDS). }\end{array}$ & $\begin{array}{l}\text { Long-term external obligations of public debtors, excluding general government (IDS code: } \\
\text { DT.DOD.DOPS.CD) }\end{array}$ \\
\hline 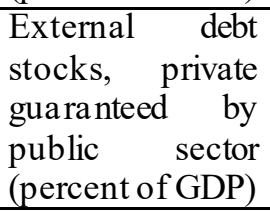 & $\begin{array}{l}\text { Authors' calculations based on } \\
\text { IMF, World Economic } \\
\text { Outlook; and International } \\
\text { Debt Statistics (IDS). }\end{array}$ & $\begin{array}{l}\text { External obligations of private debtors that are guaranteed for repayment by a public entity (IDS code: } \\
\text { DT.DOD.PRPG.CD). }\end{array}$ \\
\hline $\begin{array}{l}\text { External debt } \\
\text { stocks, general } \\
\text { government } \\
\text { (percent of GDP) }\end{array}$ & $\begin{array}{l}\text { Authors' calculations based on } \\
\text { IMF, World Economic } \\
\text { Outlook; and International } \\
\text { Debt Statistics (IDS). }\end{array}$ & $\begin{array}{l}\text { External debt is ba sed on residency concept for series coming from the IDS (code: DT.DOD.DEGG.CD) } \\
\text { and currency concept for series coming for IMF, World Economic Outlook. }\end{array}$ \\
\hline $\begin{array}{l}\text { Share of } \\
\text { concessional debt }\end{array}$ & $\begin{array}{l}\text { Authors' calculations based on } \\
\text { IMF, World Economic } \\
\text { Outlook; and International } \\
\text { Debt Statistics (IDS). }\end{array}$ & $\begin{array}{l}\text { Share of concessionaldebt in general government ex ternal debt. Concessional debt refers to multilateral } \\
\text { concessional debt (IDS code:DT.DOD.MLTC.GG.CD) }\end{array}$ \\
\hline $\begin{array}{l}\text { Share of official } \\
\text { debt }\end{array}$ & $\begin{array}{l}\text { Authors' calculations based on } \\
\text { International Debt Statistics } \\
\text { (IDS). }\end{array}$ & $\begin{array}{l}\text { Share of official debt in general government external debt. Official debt comprises bilateral and } \\
\text { multila teral debt(IDS code: DT.DOD.OFFT.GG.CD) }\end{array}$ \\
\hline \multicolumn{3}{|l|}{ Global } \\
\hline Oil price & $\begin{array}{l}\text { IMF, World Economic } \\
\text { Outlook. }\end{array}$ & Percent change of crude oil price \\
\hline $\begin{array}{l}\text { Non-fuel } \\
\text { commodity price }\end{array}$ & $\begin{array}{l}\text { IMF, Primary Commodity } \\
\text { Prices; } \text { Medas et al (2018). }\end{array}$ & \\
\hline $\begin{array}{l}\text { VIX Index Period } \\
\text { End }\end{array}$ & Bloomberg Finance L.P. & \\
\hline \multicolumn{3}{|l|}{ Other } \\
\hline HIPC dummy & $\operatorname{IMF}(2019)$ & Dummy equal to 1 if country is in a year between the HIPC decision and completion points. \\
\hline $\begin{array}{l}\text { Fiscal crisis } \\
\text { dummy }\end{array}$ & $\begin{array}{l}\text { Medas et al. (2018) and } \\
\text { authors' calculations. }\end{array}$ & $\begin{array}{l}\text { A year is classified as a fiscal crisis year when at least one of four criteria (credit event, exceptionally } \\
\text { la rge official financing, implicit domestic default, loss of market confidence) is met. For more details see } \\
\text { Medas et al. (2018). }\end{array}$ \\
\hline
\end{tabular}




\begin{tabular}{|c|c|c|}
\hline Variable & Source & Notes \\
\hline \multicolumn{3}{|l|}{ Other (con't) } \\
\hline Private debt & $\begin{array}{l}\text { IMF, Global Debt Database } \\
\text { (Mbaye, Moreno Badia, } \\
\text { Mbaye, and Chae 2018a). }\end{array}$ & TotalDebt, loans and securities, in percent of GDP \\
\hline $\begin{array}{l}\text { Financial } \\
\text { Openness Index }\end{array}$ & $\begin{array}{l}\text { Chinn and Ito (2006) updated } \\
\text { to } 2018 \text { a vaila ble at: } \\
\text { web.pdx.edu/ ito/Chinn- } \\
\text { Ito website.htm }\end{array}$ & $\begin{array}{l}\text { Mea sure of a country's degree of capital a ccount openness based on the binary dummy variables that codify } \\
\text { the tabulation of restrictions on cross-border financial tra nsactions reported in the IMF's Annual Report } \\
\text { on Exchange Arrangements and Exchange Restrictions (AREAER). }\end{array}$ \\
\hline
\end{tabular}

